\title{
Nickel Recycling in the United States in 2004
}

\author{
By Thomas G. Goonan
}

\section{U.S. GEOLOGICAL SURVEY CIRCULAR 1196-Z}

Version 1.1 


\section{U.S. Department of the Interior \\ KEN SALAZAR, Secretary \\ U.S. Geological Survey \\ Suzette M. Kimball, Acting Director}

U.S. Geological Survey, Reston, Virginia: 2009

Revised April 20, 2009

For product and ordering information:

World Wide Web: http://www.usgs.gov/pubprod

Telephone: 1-888-ASK-USGS

For more information on the USGS - the Federal source for science about the Earth, its natural and living resources, natural hazards, and the environment:

World Wide Web: http://www.usgs.gov

Telephone: 1-888-ASK-USGS

Any use of trade, product, or firm names is for descriptive purposes only and does not imply endorsement by the U.S. Government.

Although this report is in the public domain, permission must be secured from the individual copyright owners to reproduce any copyrighted materials contained within this report. 


\section{FOREWORD}

As world population increases and the world economy expands, so does the demand for natural resources. An accurate assessment of the Nation's mineral resources must include not only the resources available in the ground but also those that become available through recycling. Supplying this information to decisionmakers is an essential part of the USGS commitment to providing the science that society needs to meet natural resource and environmental challenges.

The U.S. Geological Survey is authorized by Congress to collect, analyze, and disseminate data on the domestic and international supply of and demand for minerals essential to the U.S. economy and national security. This information on mineral occurrence, production, use, and recycling helps policymakers manage resources wisely.

USGS Circular 1196, "Flow Studies for Recycling Metal Commodities in the United States," presents the results of flow studies for recycling 26 metal commodities, from aluminum to zinc. These metals are a key component of the U.S. economy. Overall, recycling accounts for more than half of the U.S. metal supply by weight and roughly 40 percent by value.

Suzette M. Kimball Acting Director 


\section{CONTENTS}

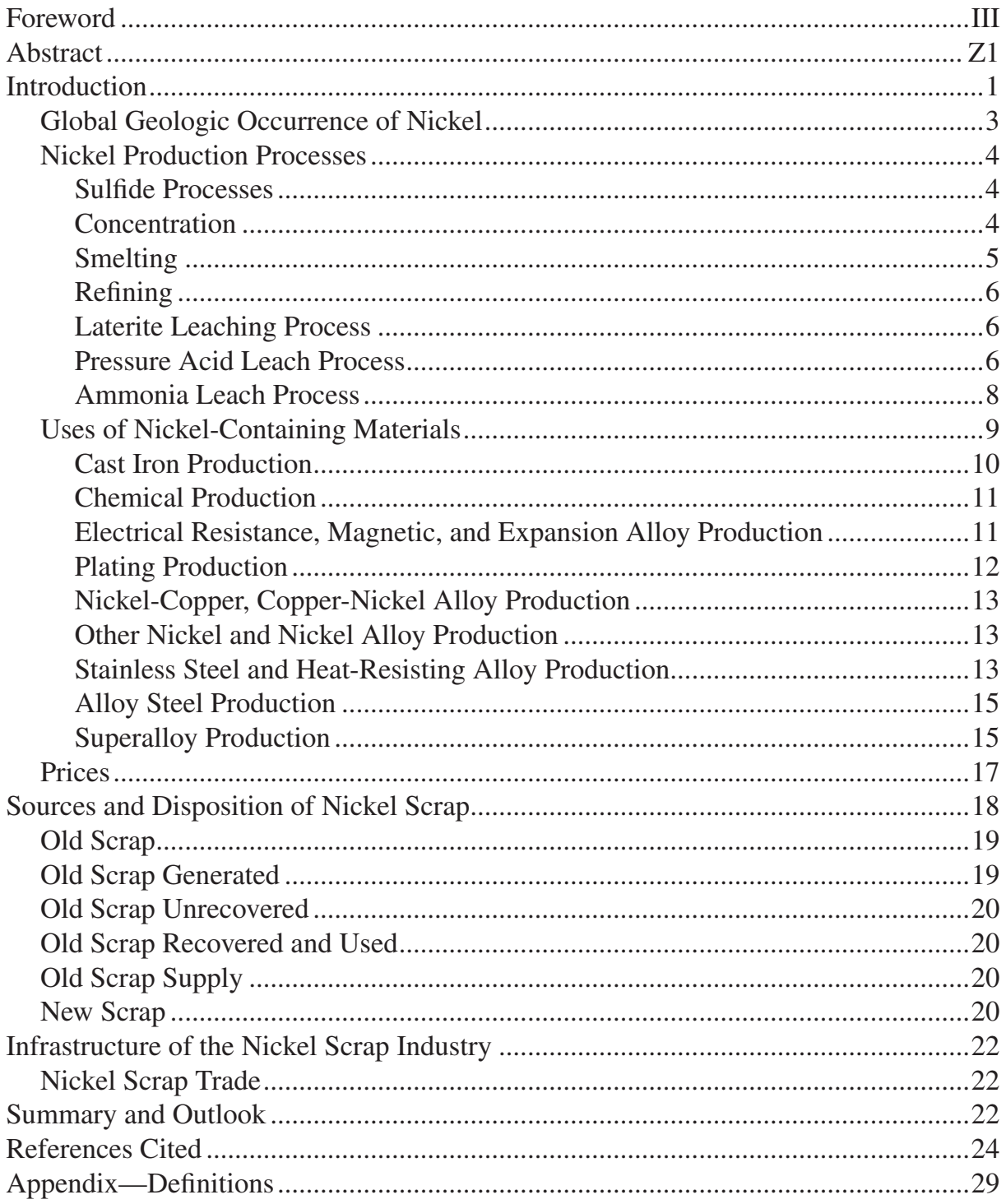

\section{FIGURES}

1. Chart showing the flow of nickel-containing products in the United States in 2004.......................................................................... Z Z2

2. Chart showing world primary nickel production by country, from 1900

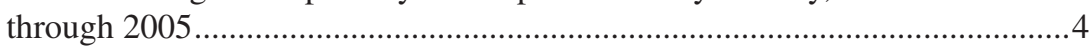

3. Chart showing world primary nickel production by region from 1900 through 2005. 
4. Diagram showing the nickel-sulfide concentrating process, the types of material that are treated, and the resulting products ....

5. Diagram showing the nickel-sulfide smelting process and the types of materials that are treated and produced.

6. Diagram showing the nickel-sulfide refining process, from sources to emissions . .

7. Diagram showing nickel-laterite pressure acid leach process, from sources to emissions

8. Diagram showing the nickel-laterite ammonia leach process, from sources to emissions .......................................................................... 9

9. Pie charts showing nickel consumption among economic categories .............10

10. Chart showing nickel consumption by end use, 1984 to 2004 ....................... 11

11. Chart showing the average annual U.S. percentage of total nickel by use category, from 1994 through 1997

12. Chart showing stainless-steel production by type, from 1965 through 2005

13. Chart showing stainless-steel production by region, from 2001 through 2005

14. Chart showing indexed price comparisons for nickel and copper, from 1955 through 2005 .

15. Chart showing nickel prices by year, 1900 through 2007

16. Chart showing indices of the average monthly prices for AISI type 304 stainless-steel scrap and nickel metal, March 1999 through February 2007.

17. Diagram showing the process flow for separating stainless steels, nickel alloys, and superalloys from mixed scrap.

18. Chart showing nickel prices and scrap availability, by quarter, from 1999 through the first quarter of 2006

\section{TABLES}

1. Salient statistics for nickel flow in the United States in 2004 ....................... Z3

2. Nickel-containing chemicals and their uses................................................. 12

3. Nickel-copper, and copper-nickel, alloys and their uses.............................13

4. World stainless-steel inputs and outputs by material type, in 2001, and fraction of total by nickel-containing raw material, alloy group, and product form .14

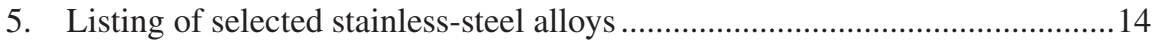

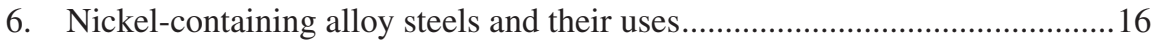

7. Selected superalloys, their composition and principal uses.........................16

8. Spent nickel-containing batteries processed by the Rechargeable Battery Recycling Corporation, the International Metals Reclamation Co. (Inmetco), and Kinsbursky, from 1999 through 2005 ............................20

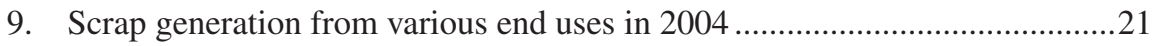

10. The principal components of spent petroleum catalysts..............................24

11. U.S. metallurgical facilities that treat nickel-containing products or wastes to recover nickel....................................................................... 24

12. Net U.S. trade in nickel-containing scrap by country, 2004 ........................25 


\section{CONVERSION FACTORS}

Most measurements in this report are in metric units, but troy ounces are used in some discussions because international gold prices are reported per troy ounce. Conversion factors are provided below.

\begin{tabular}{rll}
\hline \multicolumn{1}{c}{ Multiply } & \multicolumn{1}{c}{ By } & To obtain \\
\hline micrometer $(\mu \mathrm{m})$ & Length & \\
inch $(\mathrm{in})$. & 0.00003937 & inch $(\mathrm{in})$. \\
& 2.54 & centimeter \\
& Volume & \\
cubic meter $\left(\mathrm{m}^{3}\right)$ & 35.31 & cubic foot $\left(\mathrm{ft}^{3}\right)$ \\
& & \\
& Mass & ounce avoirdupois $(\mathrm{oz})$ \\
microgram $(\mathrm{g})$ & 0.00000003527 & ounce avoirdupois $(\mathrm{oz})$ \\
kilogram $(\mathrm{kg})$ & 2.205 & short ton $(2,000 \mathrm{pounds})$ \\
metric ton $(\mathrm{t}, 1,000 \mathrm{~kg})$ & 1.102 & megagram $(\mathrm{Mg})$ \\
ton, short $(2,000 \mathrm{lb})$ & 0.9072 & \\
\hline
\end{tabular}

Temperature in degrees Celsius $\left({ }^{\circ} \mathrm{C}\right)$ may be converted to degrees Fahrenheit $\left({ }^{\circ} \mathrm{F}\right)$ as follows:

${ }^{\circ} \mathrm{F}=\left(1.8 \mathrm{x}^{\circ} \mathrm{C}\right)+32$

Temperature in degrees Fahrenheit $\left({ }^{\circ} \mathrm{F}\right)$ may be converted to degrees Celsius $\left({ }^{\circ} \mathrm{C}\right)$ as follows:

${ }^{\circ} \mathrm{C}=\left({ }^{\circ} \mathrm{F}-32\right) / 1.8$ 


\title{
FLOW STUDIES FOR RECYCLING METAL COMMODITIES IN THE UNITED STATES
}

\section{Nickel Recycling in the United States in 2004}

\author{
By Thomas G. Goonan
}

\begin{abstract}
As one of a series of reports that describe the recycling of metal commodities in the United States, this report discusses the flow of nickel from production through distribution and use, with particular emphasis on the recycling of industrial scrap (new scrap) and used products (old scrap) in 2004. This materials flow study includes a description of nickel supply and demand for the United States to illustrate the extent of nickel recycling and to identify recycling trends. Understanding how materials flow from a source through disposition can aid in improving the management of natural resource delivery systems. In 2004, the old scrap recycling efficiency for nickel was estimated to be 56.2 percent. In 2004, nickel scrap consumption in the United States was as follows: new scrap containing 13,000 metric tons (t) of nickel (produced during the manufacture of products), 12 percent; and old scrap containing 95,000 t of nickel (articles discarded after serving a useful purpose), 88 percent. The recycling rate for nickel in 2004 was 40.9 percent, and the percentage of nickel in products attributed to nickel recovered from nickel-containing scrap was 51.6 percent. Furthermore, U.S. nickel scrap theoretically generated in 2004 had the following distribution: scrap to landfills, 24 percent; recovered and used scrap, 50 percent; and unaccounted for scrap, 26 percent. Of the 50 percent of old scrap generated in the United States that was recovered and then used in 2004, about one-third was exported and two-thirds was consumed in the domestic production of nickel-containing products.
\end{abstract}

\section{INTRODUCTION}

This study provides a snapshot, shown in figure 1, of the flow through the U.S. economy of recoverable nickel contained in various nickel-containing materials in 2004. It identifies sources of the U.S. nickel supply and its distribution with particular emphasis on the flow of nickel contained in scrap. Most recycled nickel was in the form of stainless steel scrap or alloy steel scrap. Other scrap types also are considered, such as batteries, bronzes, catalysts, chemical leachates, coinage, dusts, and liquors. Where data were unavailable for some scrap-producing sectors, a qualitative assessment of scrap generated from those categories is presented. Throughout its life cycle, nickel is subject to dissipative losses ${ }^{1}$. No attempt is made here to quantify these loses. Dissipative losses are part of unrecovered nickel (fig. 1). The data presented in figure 1 are the U.S. Geological Survey's calculated values based on information and original data from the sources indicated.

In 2004, U.S. production of nickel-containing products (alloys and chemicals) contained 222,000 metric tons (t) of nickel. Some of this production was exported $(45,000 \mathrm{t}$ of contained nickel), and the remainder (177,000 $\mathrm{t}$ of contained nickel) went into the semifabrication stage of manufacturing (downstream processing into value-added products for retail sale). The 222,000 t of nickel contained in production consumed $114,000 \mathrm{t}$ of nickel contained in primary nickel sources (from nickel metal, 90,000 t; ferronickel, 17,000 t; and other, 7,000 t), and 108,000 $\mathrm{t}$ of nickel contained in secondary sources (from old scrap, 95,000 t; and new scrap or "prompt" scrap, 13,000 t).

The nickel entering into semifabrication processes $(177,000 \mathrm{t})$ from U.S. production was supplemented by nickel contained in imports of semifinished products $(66,000 \mathrm{t})$ and nickel contained in product inventory reduction $(1,000 \mathrm{t})$ - a total of $244,000 \mathrm{t}$ of nickel. During semifabrication, scrap containing 13,000 t of nickel was generated, which went directly back into primary operations. This left materials containing 231,000 t of nickel flowing from semifabrication into the U.S. nickel products reservoir. This $231,000 \mathrm{t}$ of nickel was supplemented by nickel contained in net imports of batteries, 7,000 t of nickel-a total of 238,000 t of nickel in 2004.

In 2004, old scrap, including batteries, theoretically became available through loss of economic utility. Nickel flow, summarized in table 1 , shows this old scrap being disposed of as follows: deposited in landfills ${ }^{2}, 24$ percent; recovered and used, 50 percent; and unaccounted for, 26 percent. Of the 50 percent of U.S. old scrap that was recovered and used in 2004, about one-third was exported and two-thirds was consumed in the domestic production of nickel-containing products.

${ }^{1}$ Definitions for selected words and terms are found in the appendix.

${ }^{2}$ U.S. Geological Survey recycling reports historically do not include a flow to landfills. This report uses new information to make the estimate. 


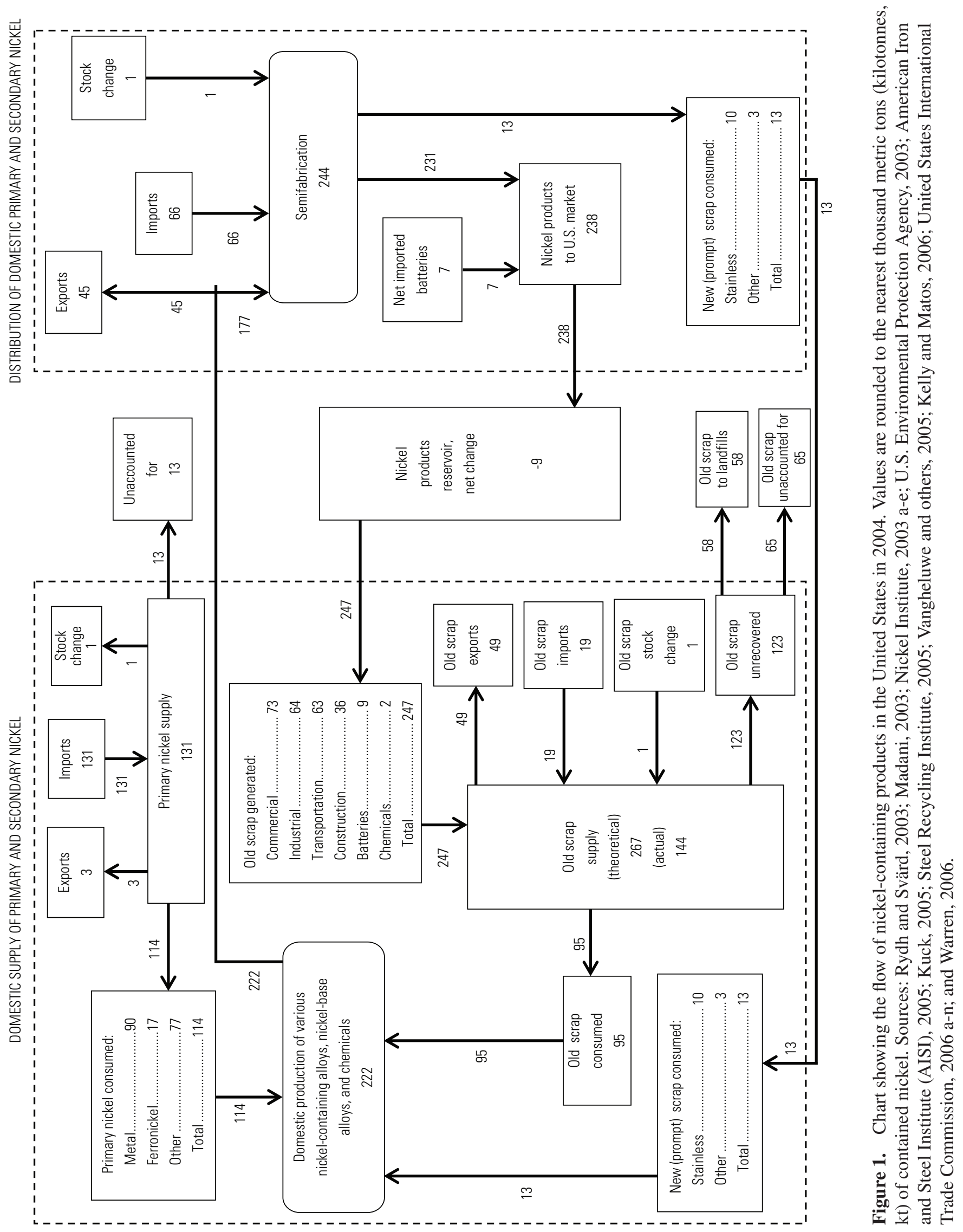


Table 1. Salient statistics for nickel flow in the United States in 2004.

[Values are in metric tons (t) of contained nickel, unless otherwise specified. Sources: Rydh and Svärd, 2003; Madani, 2003; Nickel Institute, 2003a-e; Kuck, 2005; Steel Recycling Institute, 2005; Vangheluwe and others, 2005; Kelly and Matos, 2006; United States International Trade Commission, 2006a-n; Warren, 2006]

\begin{tabular}{|c|c|}
\hline 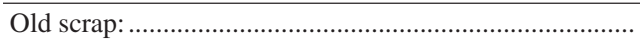 & \\
\hline Generated:.. & 247,000 \\
\hline As nonbattery scrap........... & 236,000 \\
\hline As battery scrap........ & 9,090 \\
\hline As chemical dissipation & 1,950 \\
\hline Consumed: ......... & 95,600 \\
\hline As nonbattery scrap.... & 95,200 \\
\hline Value of old scrap consumed (batteries excluded)....... & $\$ 1.180$ billion \\
\hline Recycling efficiency (batteries excluded) ... & 56.2 percent \\
\hline Supply (theoretical)...... & 267,000 \\
\hline Supply (actual) .......... & 144,000 \\
\hline Recovered and used & 124,000 \\
\hline Unrecovered ................ & 123,000 \\
\hline Deposited in landfills . & 58,400 \\
\hline Unaccounted for.......... & 64,600 \\
\hline New scrap consumed ...... & 13,000 \\
\hline New-to-old-scrap ratio ......... & $12: 88$ \\
\hline 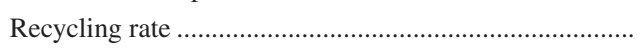 & 40.9 percent \\
\hline U.S. net exports of scrap.. & 30,200 \\
\hline Exports ........... & 49,200 \\
\hline Imports ........ & 19,000 \\
\hline Value of U.S. net exports of scrap....... & $\$ 359$ million \\
\hline 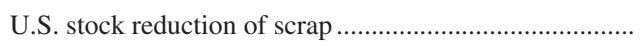 & 1,060 \\
\hline Apparent consumption & 251,000 \\
\hline Apparent supply & 264,000 \\
\hline 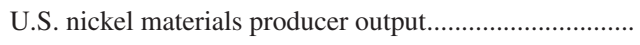 & 222,000 \\
\hline U.S. scrap consumed to produce nickel materials ........... & 51.6 percent \\
\hline
\end{tabular}

Table 1 also shows the theoretical old scrap supply, $267,000 \mathrm{t}$ of nickel, which consists of the 247,000 $\mathrm{t}$ of nickel theoretically available from recoverable old scrap generated, 1,000 $\mathrm{t}$ of nickel contained in scrap flowing from stock reduction, and 19,000 t of nickel contained in old scrap imports. The theoretical old scrap supply was distributed in three ways: old scrap consumed in the U.S. production of nickel-containing materials, 95,000 t (36 percent of theoretical supply); old scrap exported, 49,000 t (18 percent of theoretical supply); and old scrap unrecovered, 123,000 t (46 percent of theoretical supply).

In 2004, the flow of nickel contained in new (prompt) scrap from semifabrication to domestic production was 13,000 t (12 percent of nickel contained in consumed scrap), and old scrap consumed in domestic production contained 95,000 t of nickel, (88 percent of nickel contained in consumed scrap). The old scrap recycling efficiency (excluding batteries) for nickel was estimated to be 56 percent, the recy- cling rate for nickel was 41 percent, the new-scrap to oldscrap ratio for U.S. processing of nickel-containing products was 12:88 (1:7.3), and the percentage of nickel in U.S.-made nickel-containing products attributable to nickel recovered from nickel-containing scrap materials was 52 percent.

\section{GLOBAL GEOLOGIC OCCURRENCE OF NICKEL}

Nickel is the Earth's sixteenth most abundant metal, and its average crustal abundance by weight is about 0.008 percent (Smith and Huyck, 1999). The bulk of that nickel is believed to be concentrated in the Earth's core. Geologic studies indicate that most nickel deposits are hosted in ultramafic rocks, such as peridotite and serpentinite. These are igneous rocks that are low in quartz and feldspar but high in ferromagnesian silicates. The average nickel content by weight for ultramafic rocks is about 0.20 percent (Turekian and Wedepohl, 1961). This estimate was later revised to 0.15 percent (Goles, 1967). These values are too low to make nickel mining feasible using current technology.

Because nickel tends to chemically behave as iron and can be readily incorporated into either silicates or sulfides, the element is less likely to be concentrated in an economically viable deposit than less abundant elements, such as copper and lead. In order for nickel to be rich enough to mine, natural processes must occur that help to concentrate the nickel.

Nickel laterites are formed by the weathering (usually by abundant rainfall and low erosion) of ultramafic rocks. As the rocks weather, nickel, iron, and sometimes cobalt are taken into solution by descending meteoric water and are redeposited at greater depth, producing a zone of enrichment. The water is initially acidic because of the presence of organic acids and dissolved carbon dioxide. As the metal-containing water descends, it reacts with the bedrock and may become more basic. If so, the cobalt and iron tend to precipitate out first, forming a limonite zone that averages by weight 0.8 percent to 1.5 percent nickel and is rich in nickeliferous goethite $[(\mathrm{Fe}, \mathrm{Ni})$ $\mathrm{OOH}$. Further down, a point is reached where the bulk of the nickel precipitates out, together with the accompanying magnesium and silica. This second zone of enrichment typically contains by weight 1.8 percent to 3.5 percent, and the principal ore mineral is garnierite $\left[\left(\mathrm{Mg}>>\mathrm{Fe}, \mathrm{Ni}_{3}\right)_{3} \mathrm{Si}_{2} \mathrm{O}_{5}(\mathrm{OH})_{4}\right]$.

Nickel-sulfide deposits are formed by igneous or metamorphic activity, such as the intrusion of molten ultramafic rock or the alteration of the host rock by hydrothermal solutions. Some of the more well known sulfide deposits include the Jinchuan deposit in Gansu Province, China; the Kambalda and Mount Keith deposits in Western Australia, Australia; the Sudbury deposit in Ontario, Canada; and the Russian Kola deposits. The principal ore minerals found in these deposits are pentlandite $\left[(\mathrm{Fe}, \mathrm{Ni})_{9} \mathrm{~S}_{8}\right]$ and pyrrhotite $\left(\mathrm{Fe}_{1-x} \mathrm{~S}\right)$. Millerite (NiS) is regarded as a secondary, supergene (formed by descending water) mineral at Sudbury but also can occur as a principal mineral in some types of deposits that were formed 
at lower temperatures. Heazlewoodite $\left(\mathrm{Ni}_{3} \mathrm{~S}_{2}\right)$, niccoline (niccolite), a nickel arsenide (NiAs), and the various linnaeite end members $\left[(\mathrm{Co}, \mathrm{Ni}, \mathrm{Fe}, \mathrm{Cu})_{3} \mathrm{~S}_{4}\right]$ are normally present in minor amounts. At Sudbury, pentlandite and pyrrhotite are frequently associated with chalcopyrite $\left(\mathrm{CuFeS}_{2}\right)$ and, to a lesser degree, cubanite $\left(\mathrm{CuFe}_{2} \mathrm{~S}_{3}\right)$. As a result, copper is an important byproduct for Falconbridge Limited (Xstrata) and Inco Limited, the two nickel mining companies, which operated in 2004 in the Sudbury Basin. Cobalt and platinum-group metals also are being recovered from the sulfide concentrate.

Figure 2 shows primary nickel production by country for the period 1900 through 2005. Worldwide annual nickel production increased by about 5 percent per year between 1950 and 2005. In 2005, the five most productive countries (ordered by production reported in $t$ of contained nickel) were: Russia $^{3}$, 315,000 t; Canada, 198,000 t; Australia, 181,000 t; Indonesia, 160,000 t; and New Caledonia, 112,000 t. These five countries ( 23 percent of producing countries) accounted for 53 percent of world nickel production.

${ }^{3}$ Figure 2 shows nickel production for the Former Soviet Union. In 2005, Russia comprised 99 percent of Former Soviet Union nickel production.
Figure 3 shows the trends in primary nickel production by region for the period 1900 through 2005 .

\section{NICKEL PRODUCTION PROCESSES}

Because nickel occurs both in sulfide and oxide ores, different processes are used to treat each type of ore in order to extract nickel and associated coproducts and byproducts for market. Two-thirds of the nickel produced is recovered from sulfide deposits, which are mined mainly underground, whereas the remaining one-third is from laterites mined at the surface (Pointon, 2001). Environment Australia (1999) describes the processes used for treating nickel ores.

\section{SULFIDE PROCESSES}

Nickel-sulfide processing can be separated into the following three processing stages: concentration, smelting, and refining.

\section{CONCENTRATION}

Concentration is a process that separates non-nickelcontaining minerals from nickel-containing minerals, which

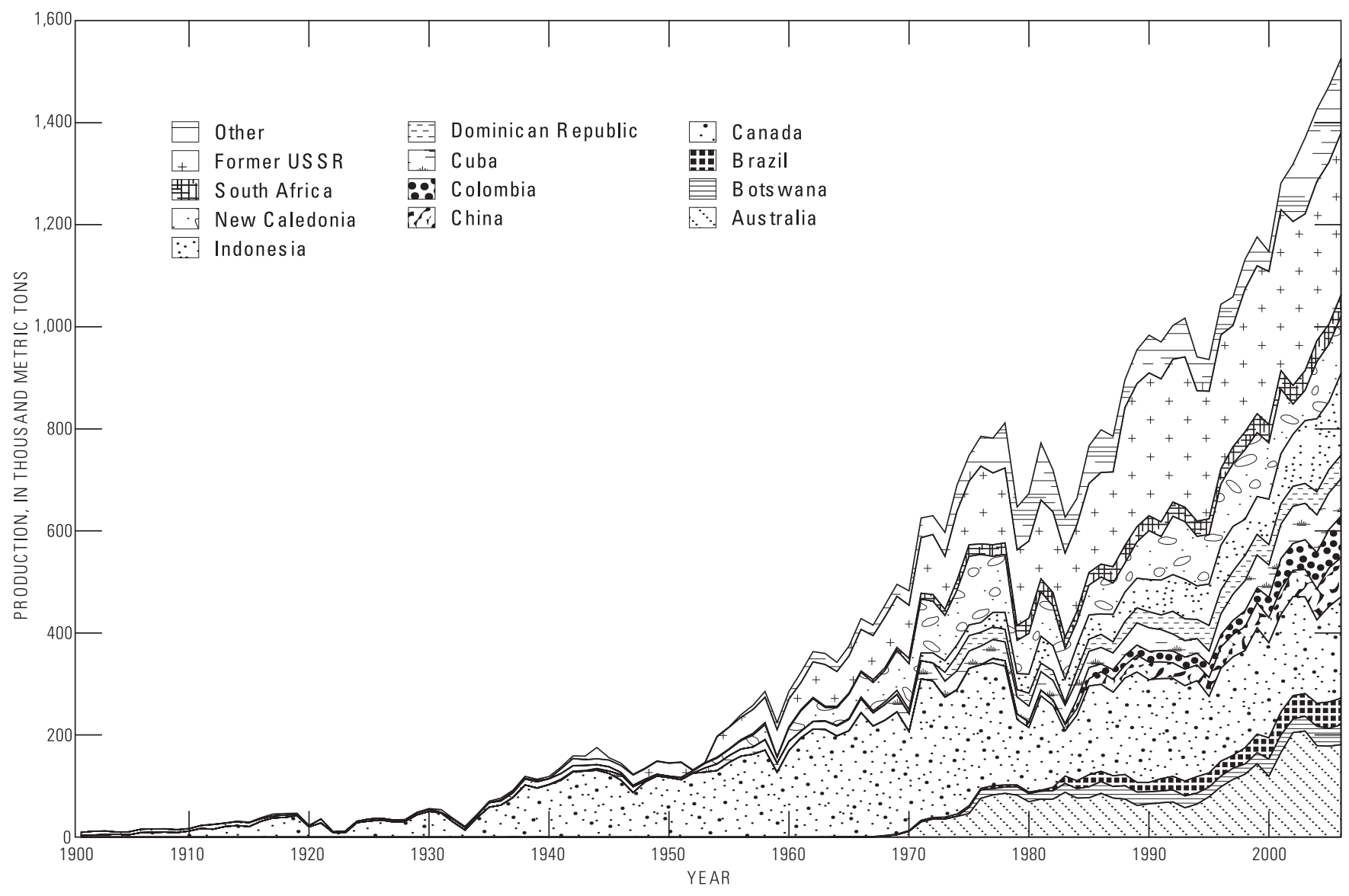

Figure 2. Chart showing world primary nickel production by country, from 1900 through 2005 . Values are in thousand metric tons of nickel. Source: Glenn J. Wallace, U.S. Geological Survey, written commun., 2006. 


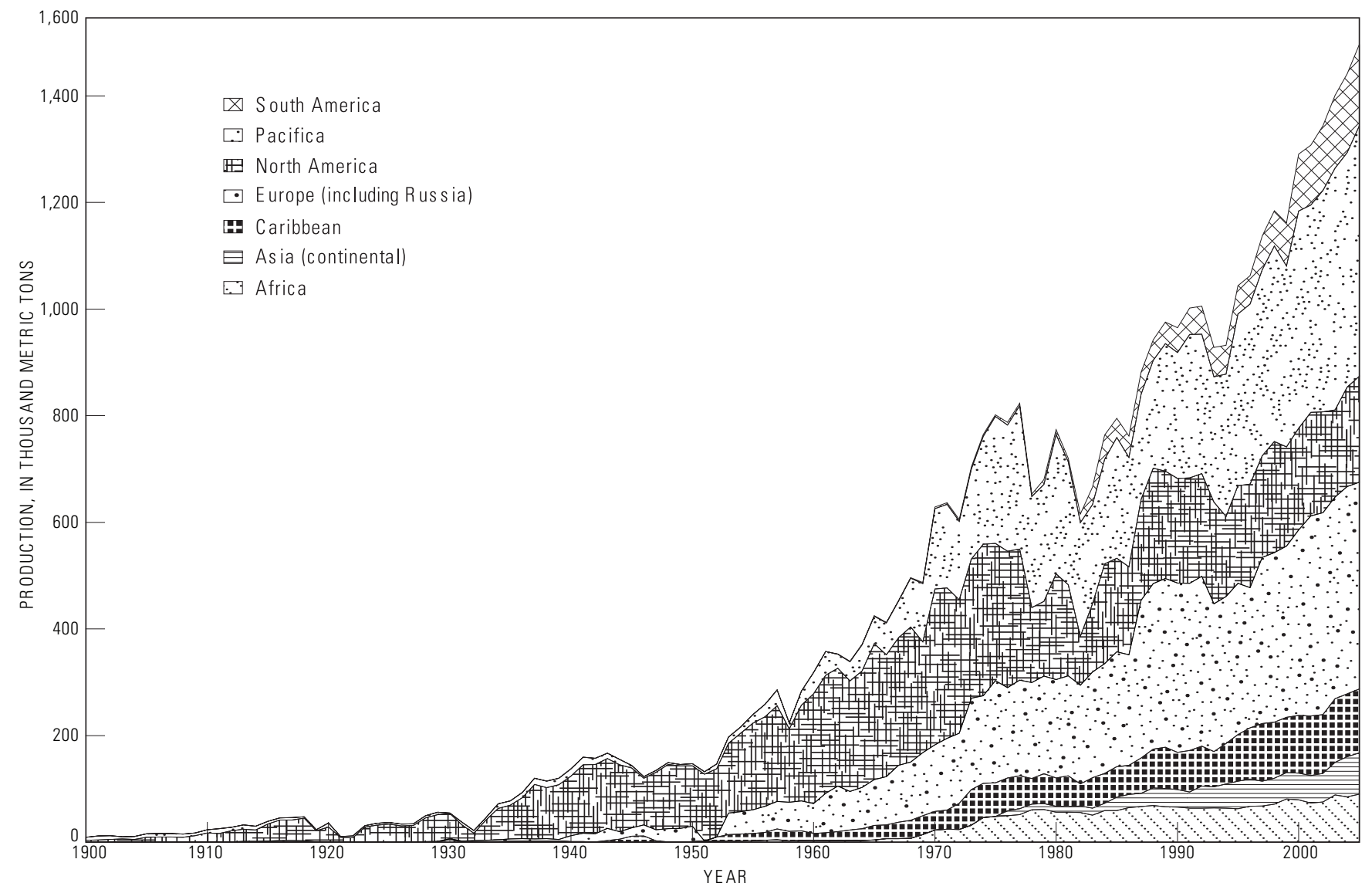

Figure 3. Chart showing world primary nickel production by region from 1900 through 2005 . Values are in thousand metric tons of nickel. Source: Glenn J. Wallace, U.S. Geological Survey, written commun., 2006.

allows downstream processes to work with materials that have much higher nickel concentrations than are contained in the ore. The ore is crushed and ground to make particles that are at least as small as the mineral grains that constitute the ore. Water and proprietary chemicals, which are prepared to take advantage of the property variations among different minerals, are added and the resulting slurry is fed into a rotating mill, where heavy steel rods or balls grind the mix into a fine pulp. The pulp from the mills is treated in flotation cells where the mixture is agitated with compressed air. The agitation, together with the compressed air, causes bubbles to form. Nickel-sulfide particles attach to the bubbles and float to the surface, which produces froth that is concentrated in nickel. The froth is collected from the surface of the cell and re-treated in the same way repeatedly, which increases the nickel content of the resulting concentrate each time. The concentration process results in a nickel concentrate that recovers more than 90 percent of the nickel originally contained in the ore. The concentrate, which contains 10 to 20 percent nickel, is then filtered and dried before being sent to a smelter. Figure 4 shows the smelting process, the types of material that are treated, and the result- ing products. For polymetallic ores, this process would be adjusted.

\section{SMELTING}

Smelting occurs in two stages. Dry nickel concentrate is mixed with flux (silica sand) and recycled furnace dust. The mixture is fed into the reaction shaft of a flash furnace. In the shaft, this mixture chemically reacts with oxygenated hot air (that is, the mixture oxidizes), which releases light (the flash) and sufficient heat to produce a fused (hot liquid) mixture. The fused mixture falls into a settler bath where matte (a nickel-enriched liquid) and slag (a nickel-poor liquid) separate because matte and slag are immiscible (that is, like water and oil, they do not mix.) The oxidizing reaction between sulfur and oxygen in the furnace shaft is exothermic (heat releasing) and provides most of the heat requirement; the balance may be supplied by natural gas. The matte (30 to 40 percent nickel) is collected and placed into a converter, where the nickel content is upgraded by blowing air into it to oxidize the remaining iron sulfides. Converter products are high-grade matte (65 to 74 percent nickel) and an iron-rich slag. Figure 5 illustrates this process and shows the type of material treated and the resulting products. 


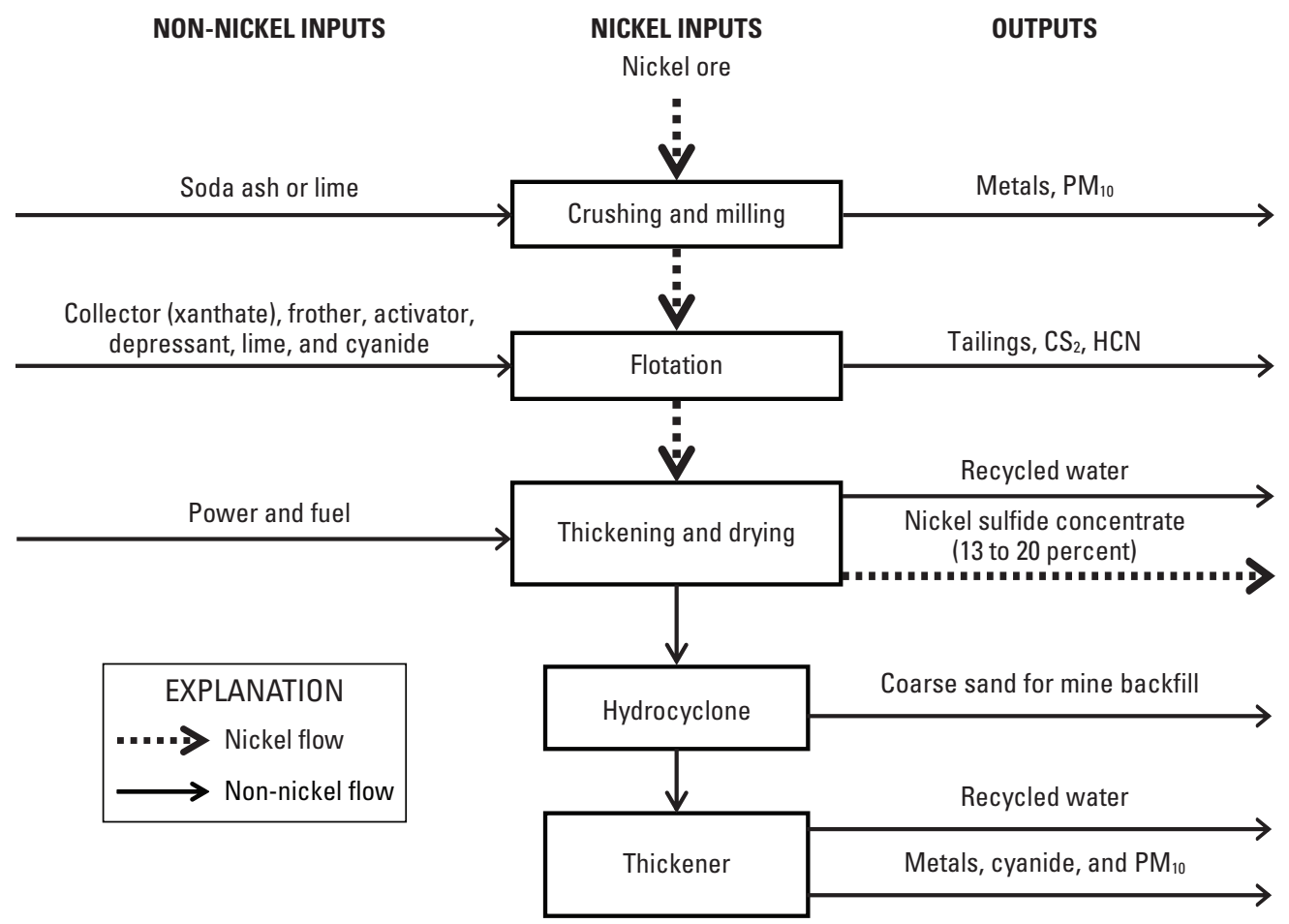

Figure 4. Diagram showing the nickel-sulfide concentrating process, the types of material that are treated, and the resulting products. The notation $\mathrm{PM}_{10}$ is used to describe particles present in the air that have a diameter less than or equal to 10 micrometers. Measurements of the amount of $\mathrm{PM}_{10}$ particles in air are reported in micrograms of material per cubic meter of air. The chemicals shown are $\mathrm{CS}_{2}$ (carbon disulfide) and $\mathrm{HCN}$ (hydrogen cyanide). Source: Environment Australia (1999, p. 6).

\section{REFINING}

Refining is a process that has several steps. The resulting product is nickel briquette ( $>99$ weight percent nickel). Figure 6 shows an example of a nickel refining process. Various other processes convert the nickel matte into marketable products. These processes remove residual iron sulfides by leaching with ammonia, followed by progressive removal of valuable components by differential precipitation. Refining includes these steps:

Leaching.-Finely ground nickel matte mixes with process liquor (recycled from the final leaching tank), and the mixture flows into autoclaves for reaction with air and ammonia at high pressure. Leaching dissolves the valuable metals — nickel, copper and cobalt — but leaves iron as an insoluble residue.

Reduction.-The process liquor undergoes a 5-day reduction cycle to precipitate nickel powder. The cycle commences with nucleation (the generation of fine seed particles) and ends with total discharge of the vessel. Nickel in solution is reduced to nickel metal, and ferrous sulfate is oxidized to ferrous hydroxide. The nickel and liquor separate by means of gravity settling.

Liquor stripping.- Reaction with hydrogen sulfide gas in a recirculation pipe reactor system produces a precipitate, which is a mixed sulfur product. This product typically contains by weight 25 percent nickel, 25 percent cobalt and 30 percent sulfur. Electrolytic refining may be required to produce low-residual nickel metal or to recover other valuable metals, which often accompany nickel in nickel ores.

\section{LATERITE LEACHING PROCESS}

Laterites are soils that have been leached by natural rainfall. Laterite ores are soils that contain valuable minerals such as aluminum, cobalt, nickel, and sometimes platinum-group metals. As described by Bleiwas (1991), laterites are usually extracted by surface mining, and they have moisture contents up to 30 percent by weight, which necessitates a dewatering step before processing. The processing route, whether pyrometallurgical or hydrometallurgical, is dependent on ore type, with the principal criterion being the ratio of magnesium to iron (garnierite to limonite). Limonitic ores are treated hydrometallurgically, and garnieritic ores are treated pyrometallurgically. The majority of lateritic ores are processed to ferronickel (20 to 40 weight percent nickel), which is a primary nickel carrier used by steel makers for stainless-steel production. Other products of laterite ore processing are nickel-sulfide matte and nickel metal (Bleiwas, 1991). Two hydrometallurgical processes are described below.

\section{PRESSURE ACID LEACH PROCESS}

Pressure acid leaching (PAL) includes the following steps, which are illustrated in figure 7 :

Ore preparation.-Clay-rich ores are washed, then ground in ball mills. Water is added to produce slurry.

Pressure leaching.-The slurry is fed into autoclaves where sulfuric acid and steam are injected at a high pressure. Leaching dissolves the valuable metals (nickel and cobalt) into the leach solution and leaves iron as an insoluble residue. 


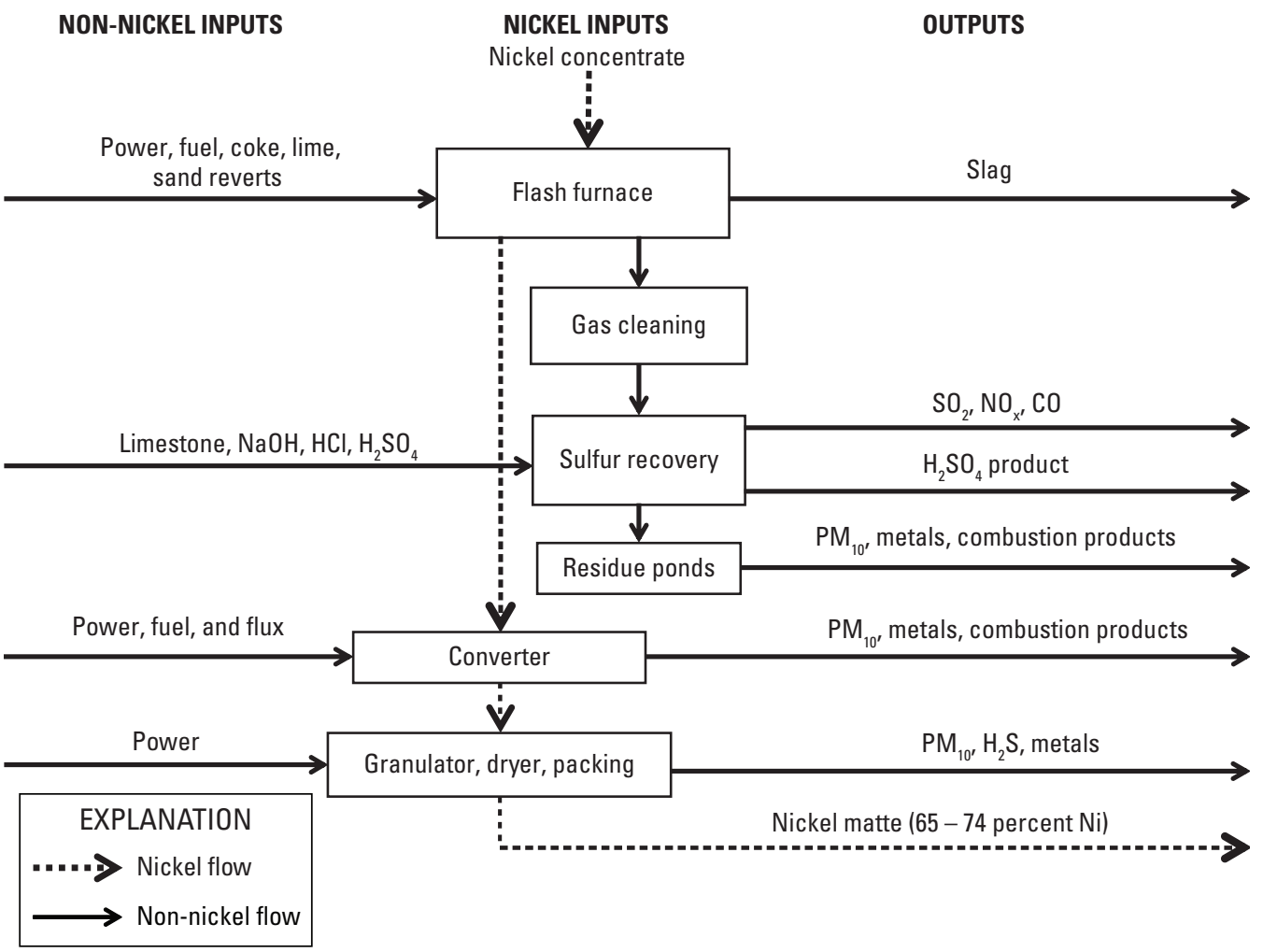

Figure 5. Diagram showing the nickel-sulfide smelting process and the types of materials that are treated and produced. The notation $\mathrm{PM}_{10}$ is used to describe particles present in the air that have a diameter less than or equal to 10 micrometers. The chemicals shown are $\mathrm{NaOH}$ (sodium hydroxide), $\mathrm{HCl}$ (hydrochloric acid), $\mathrm{H}_{2} \mathrm{SO}_{4}$ (sulfuric acid), $\mathrm{SO}_{2}$ (sulfur dioxide), $\mathrm{NO}_{x}$ (a multivariate oxide of nitrogen), $\mathrm{CO}$ (carbon monoxide), and $\mathrm{H}_{2} \mathrm{~S}$ (hydrogen sulfide). Source: Environment Australia (1999, p. 6).

NON-NICKEL INPUTS

NICKEL INPUTS

Nickel-copper matte

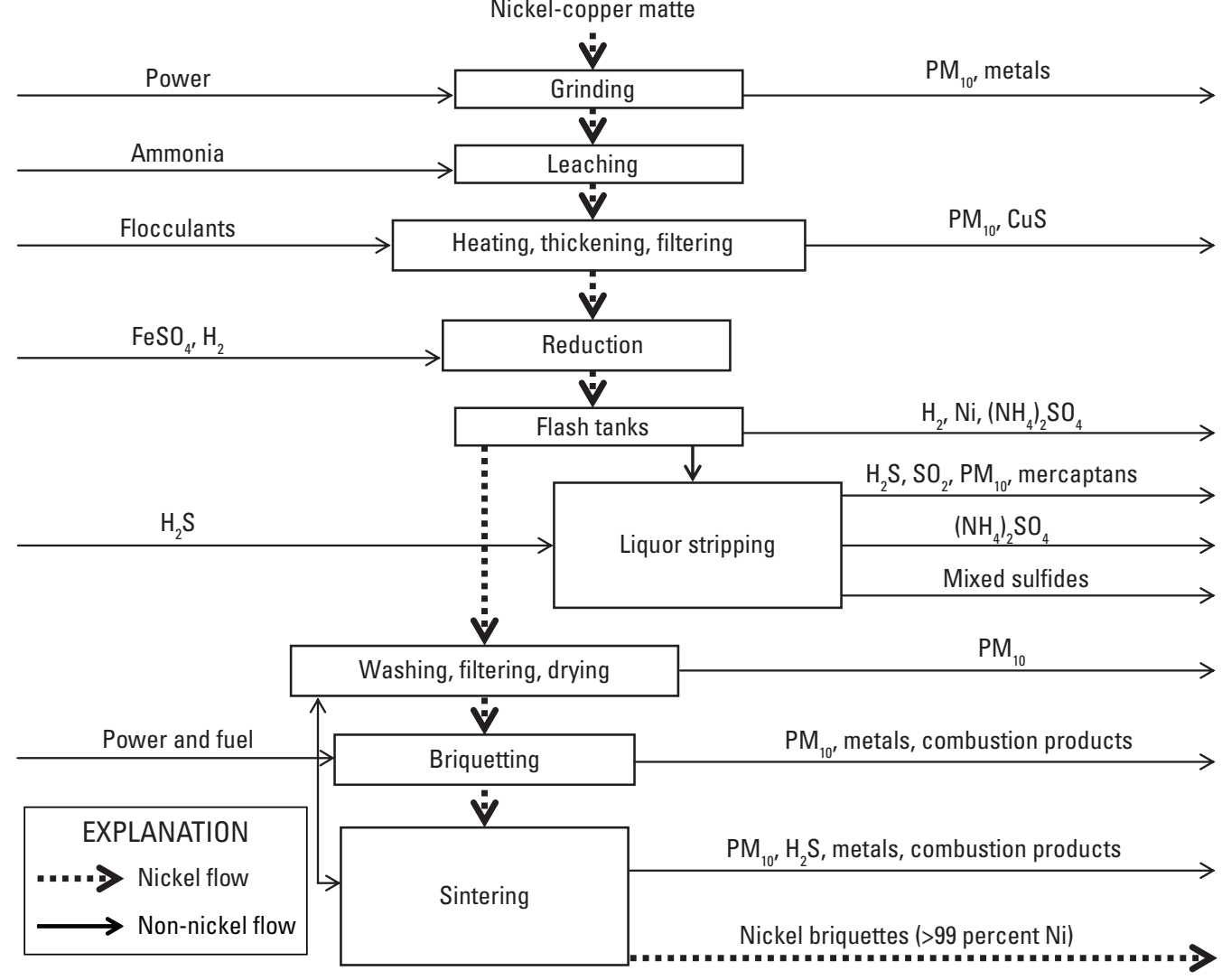

Figure 6. Diagram showing the nickel-sulfide refining process, from sources to emissions. The notation $\mathrm{PM}_{10}$ is used to describe particles present in the air that have a diameter less than or equal to 10 micrometers. Flocculants are chemical agents that gather suspended particles into aggregations. Mercaptans are chemicals having the general formula $\mathrm{RSH}$, which are analogous to alcohols and phenols, but sulfur substitutes for oxygen. The chemicals shown are $\mathrm{FeSO}_{4}$ (iron sulfate), $\mathrm{H}_{2}$ (hydrogen), $\mathrm{H}_{2} \mathrm{~S}$ (hydrogen sulfide), $\mathrm{CuS}$ (copper sulfide), $\mathrm{Ni}$ (nickel), $\left(\mathrm{NH}_{4}\right)_{2} \mathrm{SO}_{4}$ (ammonium sulfate), and $\mathrm{SO}_{2}$ (sulfur dioxide). Source: Environment Australia (1999, p. 6). 
Counter-current washing.-The leach solution is progressively cooled and passed through counter-current decantation to produce a clarified liquor.

Slurry (liquor) neutralization.-The clarified liquor is treated with limestone to increase the $\mathrm{pH}$ to neutral levels.

Mixed sulfide precipitation.-The clarified and neutralized leach solution is treated with hydrogen sulfide to precipitate nickel and cobalt sulfide, which is collected as a filter cake.

Mixed sulfide pressure leach.-This step re-dissolves the nickel and cobalt into a solution.

Solvent extraction.-This step uses organic solvents to separate nickel from cobalt, both of which enter the process dissolved in an aqueous (water-based) solution. The separation process works on two principles: organic chemicals and water do not mix (they are immiscible), and the cations (nickel and cobalt) have a different chemical preference for the two immiscible phases (nickel for organic, cobalt for aqueous).

Metal reduction.- Nickel and cobalt are stripped from their respective solutions using a concentrated ammonia $\left(\mathrm{NH}_{3}\right)$ solution or sulfuric acid $\left(\mathrm{H}_{2} \mathrm{SO}_{4}\right)$, and the metals are recovered using hydrogen gas as the reductant.

Metal briquetting/sintering.-This step produces a final standard-sized product, which is packaged for sale usually to manufacturers making alloys with other metals.
PAL technology was developed by the Canadian company Sherritt International at the city of Moa, Holguín Province, Cuba (eastern) during the late 1950s. The technology was commercially adapted to Australian laterites in 1997. Western Australia rapidly become a major processor of laterite ores, currently rivaling Cuba, Indonesia, and New Caledonia. Three nickel laterite mining and processing operations have been commissioned in Western Australia since mid-1998-Bulong, Cawse, and Murrin Murrin (Treadgold, 1998).

\section{AMMONIA LEACH PROCESS}

The basic steps in the nickel laterite ammonia leach process are as follows:

Drying and grinding - The water content of the ore is reduced, and the ore is ground to a small grain size.

Roasting - Sulfides are converted to sulfates by roasting.

Leaching and thickening-Nickel- and cobalt-sulfides and oxides are converted into nickel and cobalt ammonium sulfates in solution.

Solvent extraction - The nickel-cobalt aqueous solution is passed through steam stills to remove a range of impurities and recover ammonia. The solvent extraction process uses organic solvents to separate nickel (which adheres to the organic phase) from cobalt (which follows the aqueous phase).

\section{OUTPUTS}

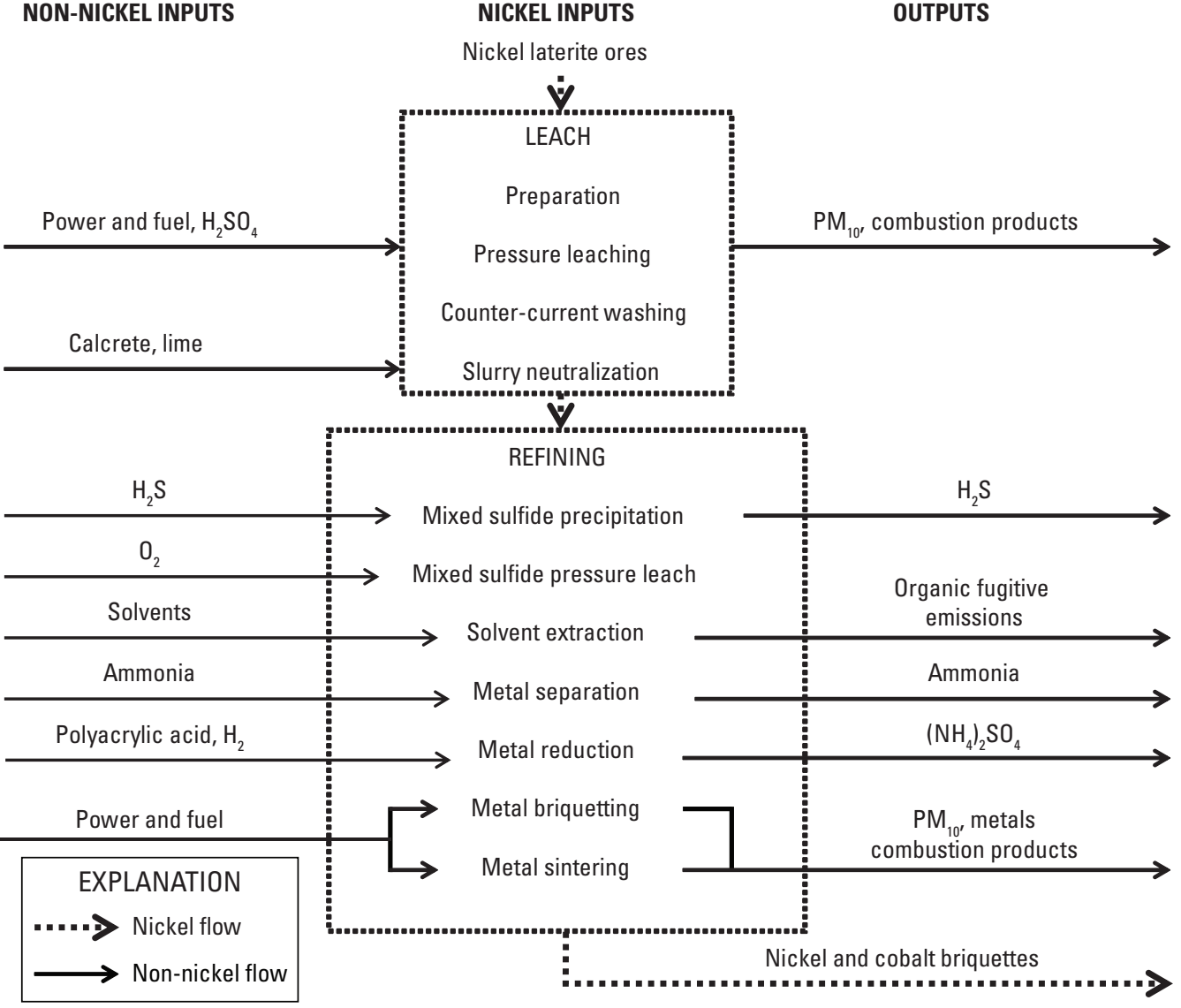

Figure 7. Diagram showing nickel-laterite pressure acid leach (PAL) process, from sources to emissions. The notation $\mathrm{PM}_{10}$ is used to describe particles present in the air that have a diameter less than or equal to 10 micrometers. Calcrete is a conglomerate of gravels cemented in calcium carbonate. Polyacrylic acid is an organic-based acid found in paints and varnishes. Fugitive emissions are uncollected emissions. Chemicals shown are $\mathrm{H}_{2}$ (hydrogen), $\mathrm{H}_{2} \mathrm{SO}_{4}$ (sulfuric acid), $\mathrm{H}_{2} \mathrm{~S}$ (hydrogen sulfide), $\mathrm{O}_{2}$ (oxygen), and $\left(\mathrm{NH}_{4}\right)_{2} \mathrm{SO}_{4}$ (ammonium sulfate). Source: Environment Australia (1999, p. 11). 
Steam stripping-Nickel is subsequently stripped from the nickel-loaded organic solvent to return nickel to an aqueous phase for further processing.

Calcining - The solution is filtered, and the filter cake is fed into a rotary furnace for calcining (heating under oxidizing conditions) to nickel oxide.

Reduction-Nickel oxide is further treated with hydrogen in the furnace to produce a range of nickel and nickeloxide products.

The process flow diagram for one type of ammonia leaching is presented in figure 8 .

\section{USES OF NICKEL-CONTAINING MATERIALS}

Nickel performs well under conditions of high temperature and high stress; therefore, nickel-containing alloys are essential in such applications (turbines, jet engines). Nickel alloys are resistant to corrosion, facilitate chemical reactions through catalysis, and are aesthetically pleasing. Nickel alloys contain other metals (such as aluminum, chromium, cobalt, copper, and iron). Nickel chemicals are used in battery manufacturing, electroplating, and hydrogenation of fats and for pigmentation. Nickel can be fabricated into desired forms and shapes by every major metalworking techniquecasting, drawing, extrusion, forging, machining, or rolling.
Nickel in alloyed and unalloyed forms is suitable for use in a wide variety of products for the consumer and capital goods markets. The largest markets for nickel are (in descending order) commercial (29 percent), industrial (27 percent), transportation (24 percent), and building and construction materials (20 percent) (Nickel Institute, 2003a-d). Figure $9 A-D$ shows the consumption of nickel among the economic categories: commercial, industrial, transportation, and building and construction, in the United States, for the year 2003.

Figure 10 shows nickel consumption among various downstream nickel-using manufacturing tracks for the period 1984 to 2004. Stainless steel consistently has accounted for more than 60 percent of nickel consumption for the period. Except for the dramatic increase in nickel consumption for electroplating in 1989, there are no significant trends to report regarding the end uses of nickel.

The U.S. Geological Survey categorizes and reports nickel consumption among 10 downstream nickel-using manufacturing tracks, including the following: cast iron; chemicals and chemical uses; electric, magnetic and expansion alloys; electroplating; nickel-copper and copper-nickel alloys; other nickel and nickel alloys; stainless and heatresisting alloys; alloy steel; superalloys; and other (Kuck, 2005). Figure 11 shows the percentage of nickel consumption by these designated categories.

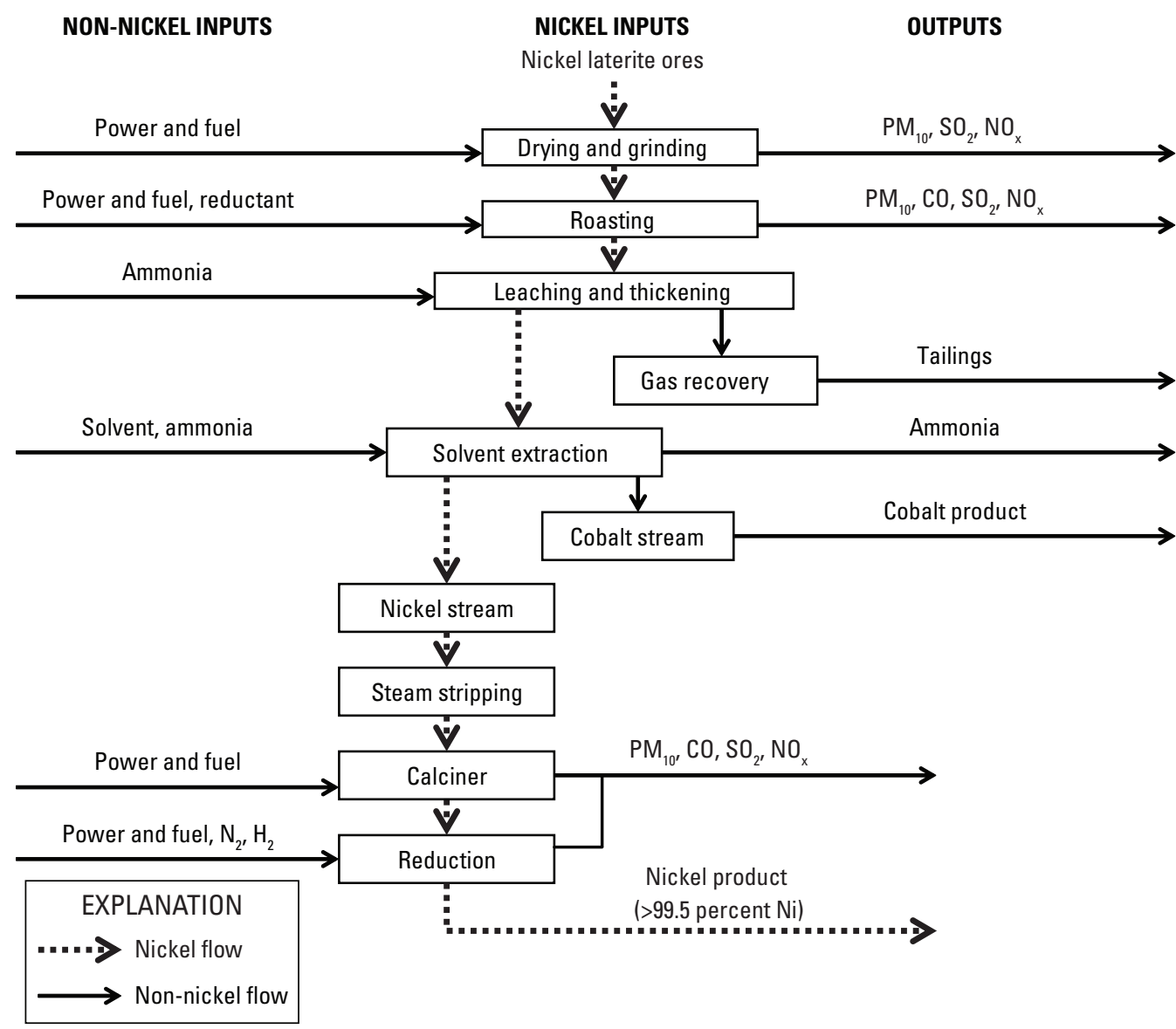

Figure 8. Diagram showing the nickel-laterite ammonia leach process, from sources to emissions. The notation $\mathrm{PM}_{10}$ is used to describe particles present in the air that have a diameter less than or equal to 10 micrometers. A reductant (for example, carbon) is an element used to replace another element (for example, iron) in a compound (for example, $\mathrm{Fe}_{3} \mathrm{O}_{4}$ ) to obtain the sought-after element (Fe-iron) separate from the original compound. Tailings are a mixed residue of unwanted materials. The chemicals shown are $\mathrm{N}_{2}$ (nitrogen), $\mathrm{H}_{2}$ (hydrogen), $\mathrm{SO}_{2}$ (sulfur dioxide), $\mathrm{NO}_{x}$ (a multivariate oxide of nitrogen), and $\mathrm{CO}$ (carbon monoxide). Source: Environment Australia (1999, p. 13). 


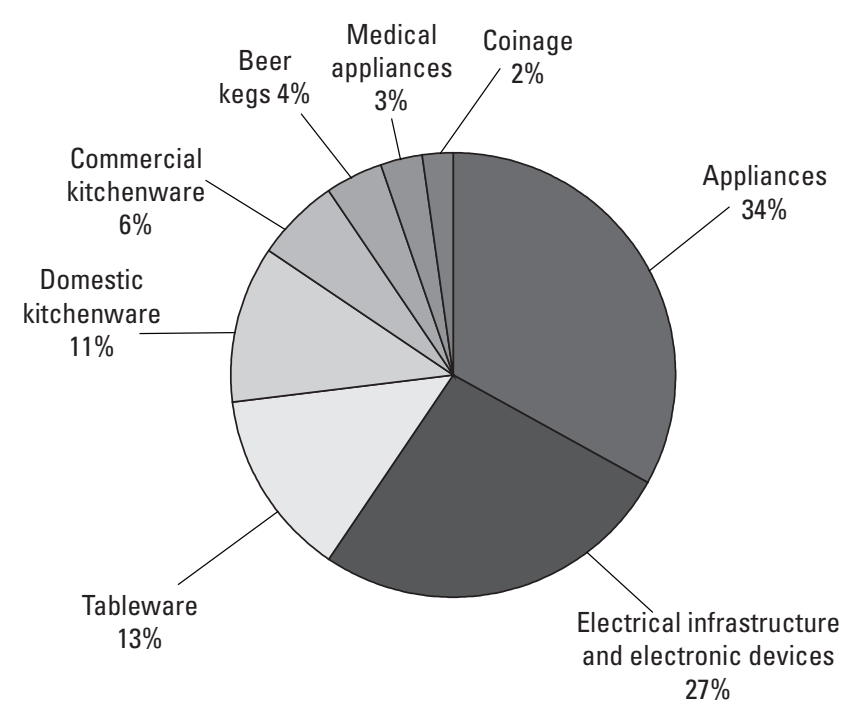

$A$

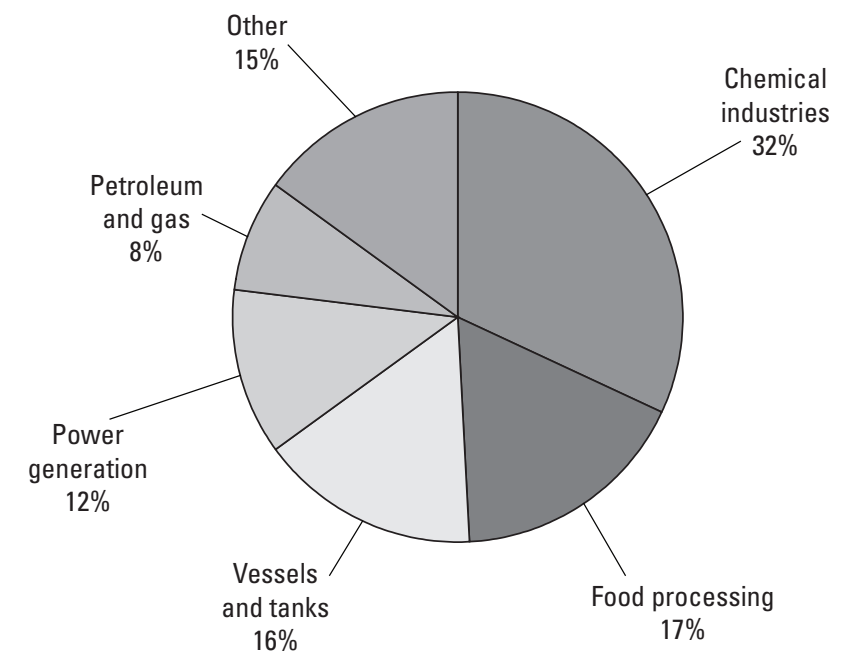

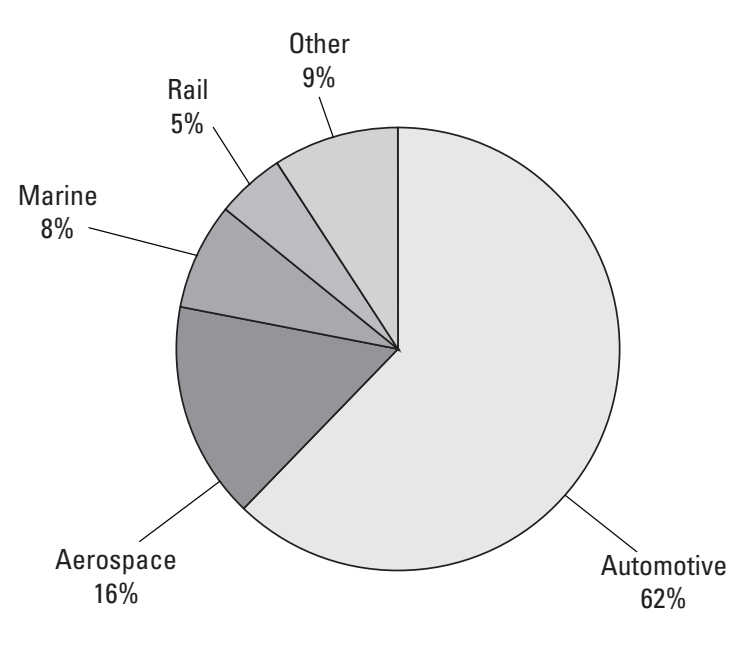

C

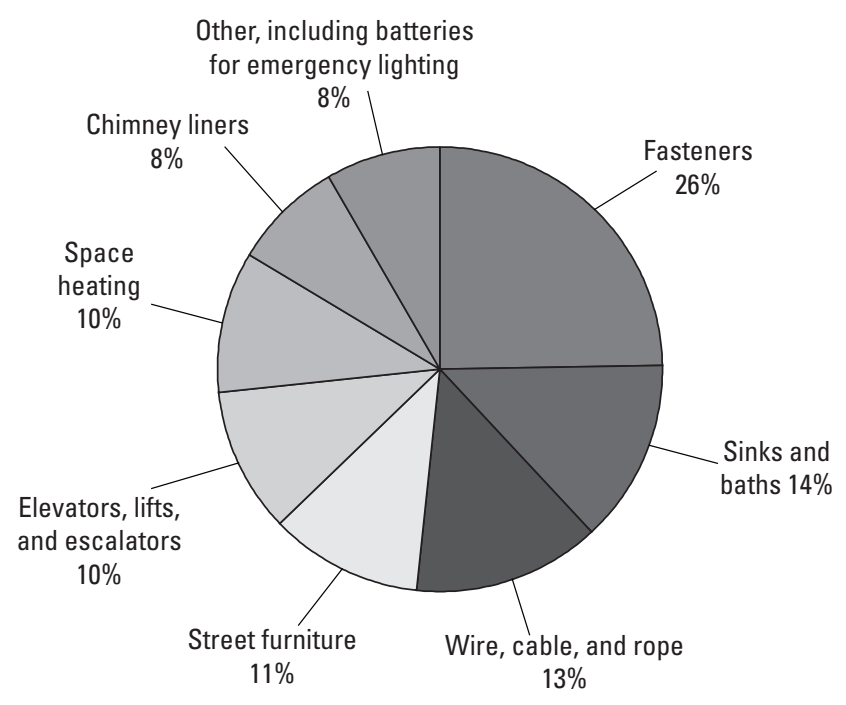

$D$

Figure 9. Pie charts showing nickel consumption among economic categories in the United States in 2003. Values are in percentage. A, Commercial (Source: Nickel Institute, 2003a). B, Industrial (Source: Nickel Institute, 2003b). C, Transportation (Source: Nickel Institute, 2003c). D, Building and construction (Source: Nickel Institute, 2003d).

\section{CAST IRON PRODUCTION}

For the 21-year period from 1984 through 2004, the annual primary nickel used in cast iron production ranged between $60 \mathrm{t}$ and 1,400 $\mathrm{t}$ of nickel, and the average was $600 \mathrm{t}$ [calculated from data provided by Kelly and Matos (2006)]. After 1990, some of the information about actual use was withheld from reporting owing to consolidation of producers; actual production is included in the undistributed category.

Pearlitic cast iron contains between 0.5 and 2 percent nickel and up to 0.8 percent chromium and up to 0.6 percent molybdenum and is used for many general castings. High carbon nickel-chromium-molybdenum (Ni-Cr-Mo) cast iron is useful for resisting thermal shock in applications such as diecasting moulds and brake drums. The nickel and chromium give the desired closeness of grain, and molybdenum helps to strengthen the matrix. Acicular cast iron contains carbon (2.9 to 3.2 percent), nickel (1.5 to 2.0 percent), and molybdenum ( 0.3 to 0.6 percent). Copper (between 1 and 5 percent, can replace nickel. This rigid, high-strength, shock-resistant material is used for diesel crankshafts, gears, and machine columns. 


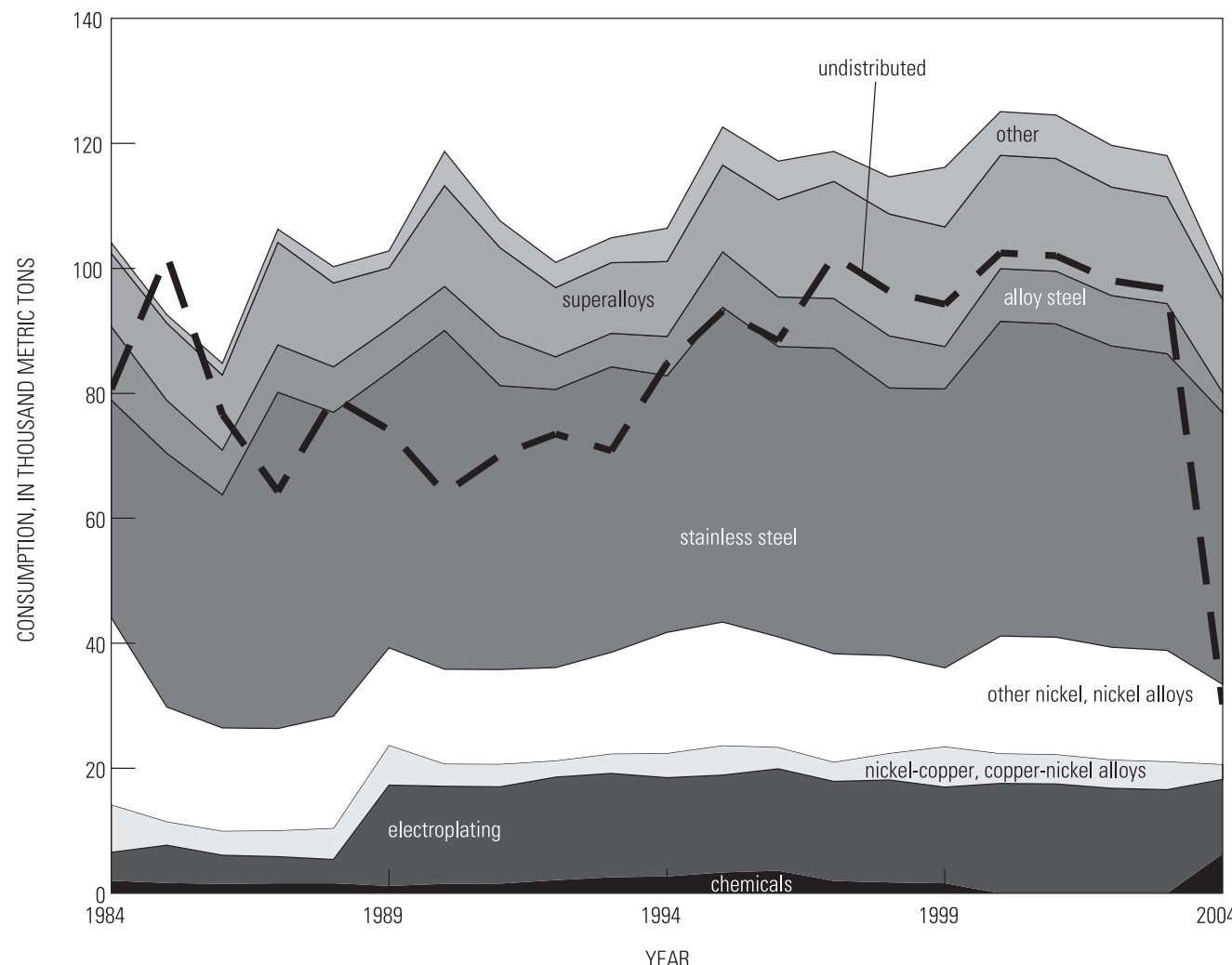

Figure 10. Chart showing nickel consumption by end use, 1984 to 2004 . Values are in metric tons contained nickel. Source: Kelly and Matos (2006).

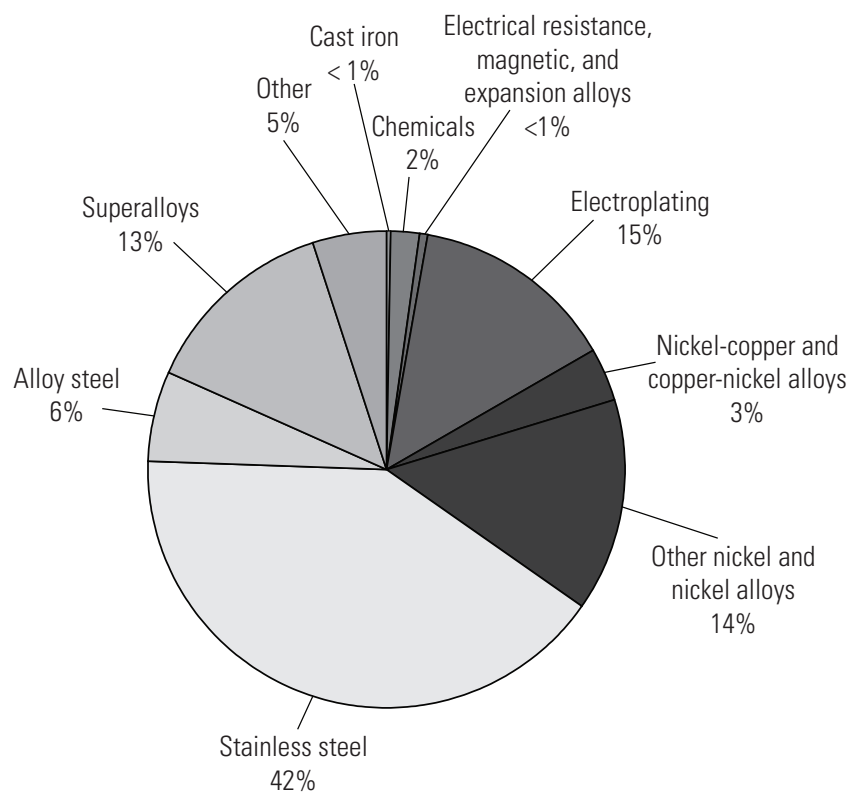

Figure 11. Chart showing the average annual U.S. percentage of total nickel by use category, from 1994 through 1997. Values are in percentage of total. Source: Kelly and Matos (2006).

Martensitic cast iron contains between 5 and 7 percent nickel with other elements and is used in abrasion-resistant applications-for example, as metal working rolls. Austenitic cast iron is nonmagnetic and contains between 11 and 33 percent nickel; however, below 20-percent nickel it is necessary to add copper (about 6 percent) or manganese (about 6 percent) to maintain fully austenitic structures. Austenitic cast iron has good resistance to corrosion and heat, a high electrical resistance, a low temperature coefficient of resistance, and a high coefficient of thermal expansion (INI International, 2006a).

\section{CHEMICAL PRODUCTION}

For the 21-year period from 1984 through 2004, nickel used in the production of chemicals ranged from 1,200 $\mathrm{t}$ to $6,300 \mathrm{t}$ of nickel per year, with an average of 2,300 $\mathrm{t}$ [calculated from data provided by Kelly and Matos (2006)]. Table 2 shows the principal nickel-containing chemicals and their most common applications.

The principal uses for nickel-containing chemicals include catalyst production (hydrogenation of food oils and petrochemical processing), electroplating, and as precursors for the production of other nickel-containing chemicals. Nickel oxide, in addition to these uses, is a source of nickel as an alloying agent in the manufacture of stainless steel (about $100 \mathrm{t}$ to $200 \mathrm{t}$ of nickel is used per year).

\section{ELECTRICAL RESISTANCE, MAGNETIC, AND EXPANSION ALLOY PRODUCTION}

For the 21-year period from 1984 through 2004, nickel used in the production of nickel-containing electrical resis- 
Table 2. Nickel-containing chemicals and their uses.

[Nickel content is the fraction of the checmicals' molecular weight. Sources: OM Group (2006); PFOnline (2006)]

\begin{tabular}{|c|c|c|}
\hline Formula & $\begin{array}{c}\text { Nickel } \\
\text { weight } \\
\text { fraction }\end{array}$ & Principal uses \\
\hline Nickel acetate tetrahydrate............ $\mathrm{Ni}\left(\mathrm{C}_{2} \mathrm{H}_{3} \mathrm{O}_{2}\right)_{2} \bullet 4 \mathrm{H}_{2} \mathrm{O}$ & 0.229 & Catalyst production, nickel electroplating, and aluminum sealing. \\
\hline 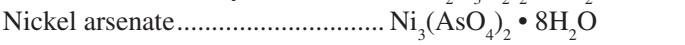 & 0.295 & Catalyst for selective fat-hardening hydrogenation. \\
\hline Nickel bromide............................. $\mathrm{NiBr}_{2}$ & 0.269 & Electroplating. \\
\hline Nickel carbonate …........................ $2 \mathrm{NiCO}_{3}^{2} \cdot 3 \mathrm{Ni}(\mathrm{OH})_{2} 4 \mathrm{H}_{2} \mathrm{O}$ & 0.327 & Catalyst production, colored glass production, and nickel electroplating. \\
\hline Nickel chloride hexahydrate .......... $\mathrm{NiCl}_{2} \bullet 6 \mathrm{H}_{2} \mathrm{O}$ & 0.247 & Electroplating. \\
\hline Nickel cyanide tetrahydrate .......... $\mathrm{Ni}(\mathrm{CN})_{2} \bullet 4 \mathrm{H}_{2} \mathrm{O}$ & 0.486 & Chemical conversion of acetylene to butadiene. \\
\hline Nickel fluoride ............................... $\mathrm{NiF}_{2}$ & 0.607 & Coatings and surface preparations. \\
\hline Nickel formate dihydrate $\ldots \ldots \ldots \ldots . . . . . . . \mathrm{Ni}(\mathrm{HCOO})_{2} \cdot 2 \mathrm{H}_{2} \mathrm{O}$ & 0.318 & Catalyst for selective fat-hardening hydrogenation. \\
\hline Nickel hydroxide............................ Ni(OH) & 0.775 & Manufacture of nickel-cadmium batteries. \\
\hline Nickel iodide ................................... $\mathrm{NiI}_{2}$ & 0.316 & Inorganic chemistry (catalyst). \\
\hline Nickel oxide ................................... NiO & 0.786 & Catalyst production, stainless-steel production, nickel salts, and specialty ceramics. \\
\hline Trinickel orthophosphate ............... $\mathrm{Ni}_{3}\left(\mathrm{PO}_{4}\right)_{2} \cdot 7 \mathrm{H}_{2} \mathrm{O}$ & 0.358 & Nickel electroplating and catalyst production. \\
\hline Nickel subsulfide......................... $\mathrm{Ni}_{3} \mathrm{~S}_{2}$ & 0.733 & Inorganic chemistry (refining of other compounds). \\
\hline
\end{tabular}

tance, magnetic, and expansion alloys ranged from 30 t to $1,300 \mathrm{t}$ of nickel per year, with an average of $340 \mathrm{t}$ [calculated from data provided by Kelly and Matos (2006)]. INI International describes these three types of alloys.

Electrical resistance alloys.-These alloys contain a high nickel content and are used in instruments and control equipment to measure and regulate the electrical characteristics of the product (resistance alloys) or are used in furnaces and appliances to generate heat under electric load (heating alloys). Types of resistance alloys containing nickel include copper-nickel $(\mathrm{Cu}-\mathrm{Ni})$ alloys containing from 2 to 45 percent nickel; nickel-chromium-aluminum (Ni-Cr-Al) alloys containing from 35 to 95 percent nickel; and nickel-chromiumsilicon (Ni-Cr-Si) alloys containing from 70 to 80 percent nickel. Types of heating alloys containing nickel include nickel-chromium (Ni-Cr) alloys containing from 65 to 80 percent nickel with 1.5 percent silicon and nickel-chromiumiron (Ni-Cr-Fe) alloys containing from 35 to 70 percent nickel with 1.5 percent silicon and 1 percent niobium.

Magnetic alloys.-Soft magnetic alloys contain a highnickel content (about 79 percent nickel and 4 to 5 percent molybdenum, with the balance of the alloy being iron). These alloys have high initial magnetic permeability and low saturation induction.

Expansion alloys.-Low-expansion alloys are based on the profound effect that nickel has on the thermal expansion of iron. Alloys can be designed to have a very low thermal expansion or to display uniform and predictable expansion over certain temperature ranges. One example is the alloy Invar (64 percent iron and 36 percent $\mathrm{Ni}$ ), which has the lowest expansion of the iron-nickel alloys and maintains nearly constant dimensions during normal variations in atmospheric temperature. The addition of cobalt to the nickeliron matrix produces alloys with a low coefficient of expansion, a constant modulus of elasticity, and high strength.

\section{PLATING PRODUCTION}

For the 21-year period from 1984 through 2004, the nickel used in plating ranged from $3,800 \mathrm{t}$ to $17,600 \mathrm{t}$ per year, with an average of 13,300 $\mathrm{t}$ [calculated from data provided by Kelly and Matos (2006)].

Electroplating.-As described by Mest (2006), galvanic electroplating of nickel provides a decorative appearance because it can cover imperfections in the surface of the base metal. A brilliant finish can be made by applying a thin layer of chromium. Nickel plating provides wear resistance. Bright nickel plating is used in automotive applications such as plated wheels, bright trim, truck exhausts, bumpers, and steps to provide an aesthetic appearance. Nickel is also plated for engineering purposes where brightness is not necessary. Nickel plating provides wearability for moulds. It is also used to plate circuit boards, coins, and jewelry. The most common method for nickel plating is the Watts bath, which uses nickel sulfate and nickel chloride, among other chemicals, to produce the plated product (Mest, 2006).

Electroless nickel plating.-This method of plating is also known as chemical or autocatalytic nickel plating. In contrast to the electroplating (galvanic) technique, chemical nickel-plating baths work without an external source of current. Electroless nickel plating uses catalytic reduction of nickel ions on the surface being plated. Electroless nickel plating has the following advantages: the need for complicated jigs and anode arrangements is avoided; the throwing power of the solution is increased, providing thicker coatings; and the coating material spreads over the entire component at a uniform rate. In many cases, subsequent machining will not be required. Three main types of electroless nickel coatings are: nickel-phosphorus, nickel-boron, and poly alloys (add cobalt, iron, and tungsten to nickelphosphorus and nickel-boron alloys). Nickel-phosphorus 
is generally used for engineering applications. The most widely used technology for electroless nickel plating is the catalytic reduction of nickel ions using sodium hypophosphite in acid baths at $\mathrm{pH} 4$ to 5 and at a temperature of 85 to $95^{\circ} \mathrm{C}$. The plated materials typically contain 3 to 13 weight percent phosphorus. The alloy obtained is dependent upon the chemical composition of the solution and the operating conditions. The phosphorus content of plating materials significantly influences their chemical and physical properties, especially after heat treatment (Secretariat for Aluminum \& Environment, 2006).

The rising production of personal computers and their hard disk drives contributes substantially to the growth in electroless nickel plating. Some of the latest disk drives have a spindle holding as many as eight magnetically coated platters. The number of platters, which spin at several thousand rotations per minute, and the composition of the magnetic material coating each platter determine the capacity of the drive. The individual platters are coated with a nickel alloy that is about three-millionths of an inch thick (Duncan, 1995).

\section{NICKEL-COPPER, COPPER-NICKEL ALLOY PRODUCTION}

For the 21-year period from 1984 through 2004, the nickel used to manufacture various nickel-copper and copper-nickel alloys ranged between 2,400 $\mathrm{t}$ and 7,700 $\mathrm{t}$ of nickel per year, with an average of 4,400 $\mathrm{t}$ [calculated from data provided by Kelly and Matos (2006)]. Table 3 shows the principal nickel-copper and copper-nickel alloys and their principal properties and uses.
Nickel-copper alloys such as Monel ${ }^{\mathrm{TM}}$ (65 to 70 percent nickel) and copper-nickel alloys such as cupronickels (10 to 30 percent nickel) are used largely in marine applications where the properties sought are resistance to biofouling, corrosion, and erosion (Greetham, 2003). Nickel silver alloys (10 to 20 percent nickel), which contain copper, nickel, and zinc, are used for housewares and giftware (Smiths Metal Centres, 2006).

\section{OTHER NICKEL AND NICKEL ALLOY PRODUCTION}

This category includes wrought nickel metal products as well as nickel alloys that are included in the other categories described in this report. For the 21-year period from 1984 through 2004, the nickel used in the production of other nickel and nickel alloy materials ranged from 12,600 t and 29,900 $\mathrm{t}$ of nickel per year, with an average of 17,300 t [calculated from data provided by Kelly and Matos (2006)].

\section{STAINLESS-STEEL AND HEAT-RESISTING ALLOY PRODUCTION}

Each year, over 60 percent of the nickel consumed in U.S. primary metals operations becomes a component of stainless steel. Table 4 characterizes stainless-steel production by raw materials input, type (austenitic or other), and product form (flat—plate, sheet, and strip; long—bars, rods, tubes, and pipes). Seventy percent of austenitic alloys (and thus the bulk of nickel contained in ferrous alloys) becomes flat products; 30 percent becomes long products.

Ferritic stainless-steel alloys (the 400 series) contain from 10 to 20 weight percent chromium, which makes them

Table 3. Nickel-copper, and copper-nickel, alloys and their uses.

[Nickel and copper content are in fractions of the alloy's total weight. Sources: Greetham (2003); INI International (2006b); Smiths Metal Centres (2006)]

\begin{tabular}{|c|c|c|c|}
\hline Category & $\begin{array}{c}\text { Nickel } \\
\text { weight } \\
\text { fraction }\end{array}$ & $\begin{array}{l}\text { Copper } \\
\text { fraction }\end{array}$ & Principal properties and uses \\
\hline & & & Nickel-copper alloys \\
\hline 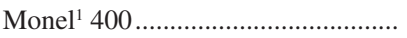 & 0.640 & 0.310 & \multirow{4}{*}{$\begin{array}{l}\text { Monel alloys are nickel-copper alloys that can be hardened by cold working. These alloys } \\
\text { have a low corrosion rate in flowing seawater; therefore; they are widely used in marine } \\
\text { applications. Monel alloys also have excellent resistance to stress corrosion cracking in most } \\
\text { freshwaters. They can be used in temperatures up to } 1,000^{\circ} \mathrm{F} \text {. These alloys have excellent } \\
\text { mechanical properties at subzero temperatures. } \\
\text { Copper-nickel alloys }\end{array}$} \\
\hline Monel R-405. & 0.630 & 0.330 & \\
\hline Monel K-500. & 0.650 & 0.295 & \\
\hline & & & \\
\hline Cupronickel, 10 percent ................... & 0.100 & 0.885 & \multirow{3}{*}{$\begin{array}{l}\text { Cupronickel alloys are used in marine applications because they exhibit low corrosion rates in } \\
\text { seawater, resistance to fouling from marine organisms, and resistance to mechanical erosion. }\end{array}$} \\
\hline Cupronickel, 20 percent ................... & 0.200 & 0.819 & \\
\hline Cupronickel, 30 percent .................. & 0.300 & 0.695 & \\
\hline & & & Nickel-silver alloys \\
\hline Nickel silver A .............................. & 0.180 & 0.650 & \multirow{5}{*}{$\begin{array}{l}\text { As a class, nickel silvers, which are named for their color, not their silver content, show suit- } \\
\text { able aesthetic qualities, low corrosion, and metal workability. They are used in housewares, } \\
\text { giftware, and milk containers. The remaining major alloying element is zinc. Low levels of } \\
\text { lead can be added to improve machinability. }\end{array}$} \\
\hline Nickel silver B ............................ & 0.180 & 0.550 & \\
\hline Leaded nickel silver ...................... & 0.125 & 0.555 & \\
\hline Dairy metal, leaded nickel silver..... & 0.203 & 0.650 & \\
\hline 25 percent leaded nickel silver........ & 0.255 & 0.655 & \\
\hline
\end{tabular}

${ }^{1}$ Monel is a trademark of Special Metals Corporation. 
iron-chromium alloys with only minimal or trace amounts of other metals. These alloys resist corrosion and hightemperature scaling (oxidation). They are magnetic because their crystal structure is body-centered-cubic. The character of these alloys makes them suitable for automotive emission control exhaust systems.

Austenitic stainless-steel alloys (the 200 and 300 series) contain 15 to 30 weight percent chromium and 2 to 20 weight percent nickel. Nickel improves surface quality, formability, and resistance to corrosion. These alloys have a crystal structure that is face-centered-cubic, which makes them nonmagnetic. They are also hardenable (enhanced physical properties through heat treatment). Typical applications include automotive trim, cookware, and processing equipment. A selection of nickel-containing stainless-steel alloys is shown in table 5 .
Figure 12 shows the history of U.S. austenitic and ferritic stainless-steel production type for the period 1965-2005.

After 1992, the ratio of austenitic to ferritic stainlesssteel production in the United States decreased (fig. 12). A possible explanation for this trend might be that nickelcontaining grades of stainless steel are more expensive, and global trade agreements have provided the opportunity for the United States to import greater quantities of the more expensive austenitic grades of stainless steel. The nickel content of total U.S. stainless-steel production in 2004 was about $156,000 \mathrm{t}$.

From 2001 through 2005, the average annual growth in world stainless-steel production was 6.2 percent (International Stainless Steel Forum, 2006a). For the same period, the average annual growth for Europe and Africa, the Americas, and Asia was 1.9, 4.6, and 10.5 percent, respectively.

Table 4. World stainless-steel inputs and outputs by material type, in 2001, and fraction of total by nickel-containing raw material, alloy group, and product form.

[Values are in fractions of total. Source: Pointon (2001)]

\begin{tabular}{|c|c|c|c|c|c|}
\hline \multicolumn{2}{|c|}{ Type of raw materials to make stainless steel } & \multicolumn{2}{|c|}{ Stainless-steel product alloy group } & \multicolumn{2}{|c|}{ Stainless-steel product form } \\
\hline Name & Weight fraction & Name & Weight fraction & Type & Weight fraction \\
\hline Stainless-steel scrap ........................... & 0.281 & 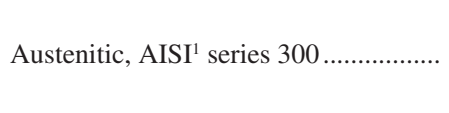 & 0.75 & $\begin{array}{l}\text { Flat (slab, sheet)..... } \\
\text { Long (bar, rod) ........ }\end{array}$ & $\begin{array}{l}0.525 \\
0.225\end{array}$ \\
\hline Primary nickel & $\begin{array}{l}0.041 \\
0.25\end{array}$ & Ferritic/Martensitic, AISI series $400 \ldots .$. & 0.188 & Flat …........................ & 0.2 \\
\hline 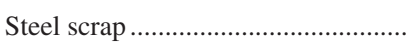 & 0.438 & High-manganese, AISI series $200 \ldots \ldots \ldots$. & 0.063 & Long .......................... & 0.05 \\
\hline
\end{tabular}

${ }^{1}$ AISI refers to the American Iron and Steel Institute.

Table 5. Listing of selected stainless-steel alloys.

[Nickel and chromium weights are in fractions of the total. Sources: AK Steel (2006); Precision Steel Warehouse, Inc. (2006); Rice Lake Weighing Systems (2006)]

\begin{tabular}{|c|c|c|c|}
\hline Name & $\begin{array}{l}\text { Nickel } \\
\text { weight } \\
\text { fraction }\end{array}$ & $\begin{array}{c}\text { Chromium } \\
\text { weight } \\
\text { fraction }\end{array}$ & Principle uses \\
\hline AISI $^{1}$ Type 202 & 0.050 & 0.180 & Hose clamps, cookware. \\
\hline AISI Type 301 & 0.070 & 0.170 & Wheel covers, springs, hose clamps, food processing equipment. \\
\hline AISI Type 302 & 0.090 & 0.180 & Formed products, drawn parts, flexible hose, household appliances, spinning operations. \\
\hline AISI Type 304 & 0.093 & 0.190 & Food equipment, tubing, architectural trim, paper and chemical processes. \\
\hline AISI Type 305 & 0.125 & 0.180 & Electronic parts that are easily deep drawn or spun. \\
\hline AISI Type 309 & 0.135 & 0.230 & $\begin{array}{l}\text { Aircraft heaters, heat-treating equipment, annealing covers, furnace parts, heat exchangers, heat-treating trays, oven } \\
\text { linings, pump parts. }\end{array}$ \\
\hline AISI Type 310 & 0.205 & 0.250 & Heat exchangers, furnace parts, combustion chambers, gas turbines, jet engines. \\
\hline AISI Type 314 & 0.205 & 0.210 & Motor shafts, which require high-temperature wear resistance. \\
\hline AISI Type 316 & 0.120 & 0.170 & Textile industries, process and pulp pumps, valves, textiles, chemicals. \\
\hline AISI Type 321 & 0.105 & 0.180 & Exhaust manifolds, boiler shells, fire walls, process equipment, pressure vessels, aircraft engine parts. \\
\hline AISI Type 330 & 0.355 & 0.185 & Furnace components, gas turbines, heat exchangers, general heat-treating equipment, neutral and cyanide salt pots. \\
\hline AISI Type 347 & 0.110 & 0.180 & Welding rods, which require resistance to high-temperature intergranular corrosion. \\
\hline
\end{tabular}

${ }^{1}$ AISI refers to the American Iron and Steel Institute. 


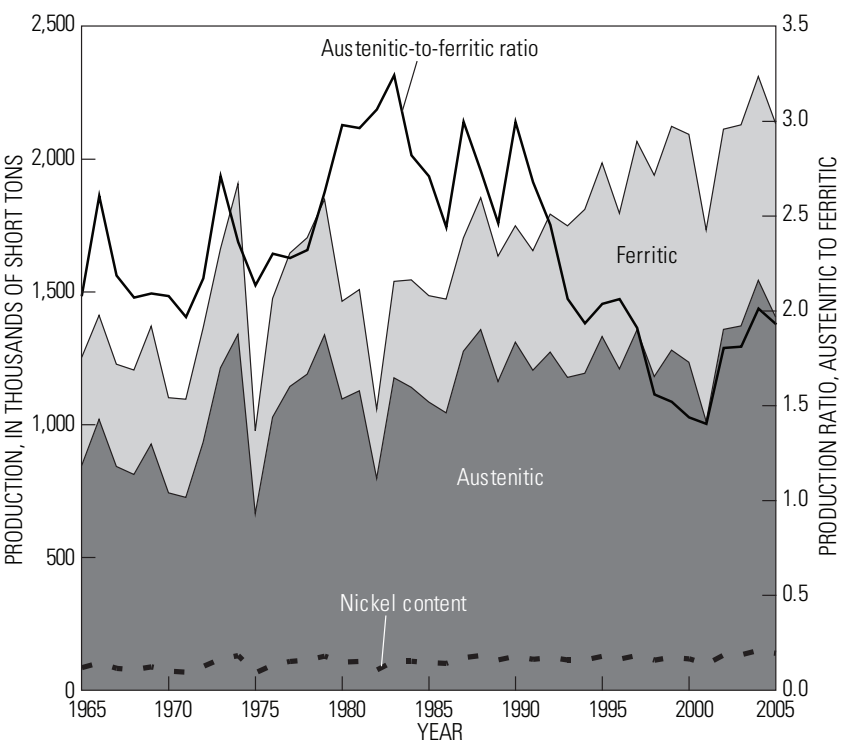

Figure 12. Chart showing stainless-steel production by type, from 1965 through 2005. Production values are in short tons stainless steel and nickel content. The austeniticferritic ratio is unitless. Source: John F. Papp, U.S. Geological Survey, written commun., 2006.

India and China fueled the significant increase in stainlesssteel production in Asia. Figure 13 shows the magnitude of stainless-steel production in the three regions.

According to Pointon (2001), some trends bode well for the growth in demand for nickel-containing stainless steel. Water-treatment and water-delivery systems must provide uncontaminated water. New and replacement watertreatment systems substitute stainless steel for cast iron and galvanized steel. The food processing industry, as it grows, will enhance the demand for nickel-containing stainless steel, which is resistant to oxidation, acid, and alkali attack. With safety and weight issues becoming more important in the transportation industry, stainless steel, which has a high energy-absorbing capability, is becoming the material of choice for passenger and cargo space-framing materials. Stainless-steel rebar provides longer life to load-bearing structures, which reduces maintenance costs.

\section{ALLOY STEEL PRODUCTION}

Alloy steels are iron based with additions of elements such as chromium (for example, American Iron and Steel Institute alloys 4037, 4130, 8630), molybdenum, and nickel and are used where high strength is required. After annealing (heating) to relieve stress from prior working, these steels can be readily cold-worked (forged at ambient temperatures). They can be heat treated to achieve specific combinations of physical properties. Table 6 lists some commonly used nickel-containing alloy steels, which range from 0.55 to 5.0 weight percent nickel. For the 21 -year pe-

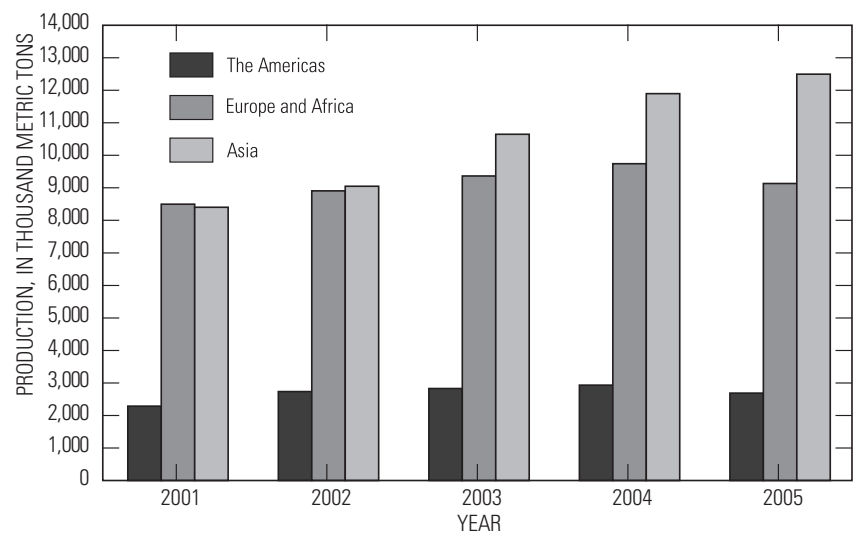

Figure 13. Chart showing stainless-steel production by region, from 2001 through 2005 . Values are in thousand metric tons. Source: International Stainless Steel Forum, 2006a.

riod from 1984 through 2004, the nickel used in alloy-steel production ranged between 3,200 and 11,800 t of nickel per year, with an average of 7,500 $\mathrm{t}$ [calculated from data provided by Kelly and Matos (2006)].

\section{SUPERALLOY PRODUCTION}

The term "superalloy" was first used shortly after World War II to describe a group of alloys developed for use in turbosuperchargers and aircraft turbine engines that required high performance at elevated temperatures. The range of applications for which superalloys are used has expanded to include aircraft and land-based gas turbines, rocket engines, and processing equipment for chemical and petroleum plants. Superalloys are particularly well suited for these demanding applications because of their ability to retain most of their strength even after long exposure times above $650^{\circ} \mathrm{C}\left(1,200^{\circ} \mathrm{F}\right)$. Their versatility stems from the fact that they combine high strength with good low-temperature ductility and excellent surface stability. Superalloys are based on Group VIIIB elements and usually consist of various combinations of chromium, cobalt, iron, and nickel, as well as lesser amounts of aluminum, molybdenum, niobium, tantalum, titanium, and tungsten. The three major classes of superalloys are nickel-, iron-, and cobalt-based alloys (Bowman, 2006).

Nickel-based superalloys are able to bear high loads at operating temperatures equal to 90 percent of their melting point. Among the most demanding applications for a structural material are those in the hot sections of turbine engines. The prominence of superalloys, most of which contain nickel, is reflected in the fact that they currently compose more than 50 percent of the weight of advanced aircraft engines (Bowman, 2006). Table 7 provides examples of superalloys.

For the 21-year period from 1984 through 2004, the nickel used in the production of superalloys ranged from 9,700 
Table 6. Nickel-containing alloy steels and their uses.

[Nickel fraction is reported as fraction of total weight. Sources: e-Funda (2006); Encore Metals, Inc. (2006)]

\begin{tabular}{|c|c|c|}
\hline Name & $\begin{array}{c}\text { Nickel } \\
\text { weight } \\
\text { fraction }\end{array}$ & Principal uses \\
\hline AISI ${ }^{1}$ Type $23 X X$ & 0.035 & $\begin{array}{l}\text { Used to manufacture components that are subjected to highly repetitive cycling stress regimes; for example, axles and crank } \\
\text { shafts. }\end{array}$ \\
\hline AISI Type $25 \mathrm{XX}$ & 0.050 & Do. \\
\hline AISI Type $31 \mathrm{XX}$ & 0.013 & Nickel-chromium steels used to manufacture gears, axles, and shafts. \\
\hline AISI Type $33 \mathrm{XX}$ & 0.035 & Heavy-duty gears, pinions, spline shafts, piston pins, transmission components, rock-drilling-bit bodies, plastic moulds. \\
\hline AISI Type $34 \mathrm{XX}$ & 0.030 & Improves elastic limit, hardenability, impact resistance, and fatigue resistance of componenets. \\
\hline AISI Type 43XX & 0.018 & Machine parts, shafting, bolts, gears, axel shafts, crankshafts, boring bars, down-hole drilling components. \\
\hline AISI Type 46XX & 0.013 & Do. \\
\hline AISI Type 47XX & 0.011 & Adds hardness, reduces brittleness, and increases toughness of components. \\
\hline AISI Type 48XX & 0.035 & Do. \\
\hline AISI Type $81 \mathrm{XX}$ & 0.003 & Improves strength, hardness, corrosion resistance, and electrical conductivity of components. \\
\hline AISI Type $86 \mathrm{XX}$ & 0.006 & $\begin{array}{l}\text { Carburized gears, splined shafts, automotive transmission components, arbors, bearings, bushings, king pins, general engi- } \\
\text { neering purposes. }\end{array}$ \\
\hline AISI Type $87 \mathrm{XX}$ & 0.006 & Do. \\
\hline AISI Type $88 \mathrm{XX}$ & 0.006 & Do. \\
\hline AISI Type 93XX & 0.033 & Automotive gears. \\
\hline AISI Type $94 \mathrm{XX}$ & 0.005 & Do. \\
\hline
\end{tabular}

${ }^{1}$ AISI refers to the American Iron and Steel Institute.

Table 7. Selected superalloys, their composition and principal uses.

[Nickel and other metal content are in fractions of the total alloy weight. Sources: Bhadeshia (2003); and Bowman (2006)]

\begin{tabular}{|c|c|c|c|}
\hline Name & $\begin{array}{c}\text { Nickel } \\
\text { weight } \\
\text { fraction }\end{array}$ & Other fractions & Principal uses \\
\hline 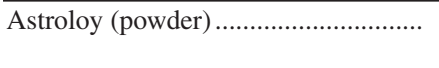 & 0.55 & $\begin{array}{l}\text { Cr 0.15, Co 0.17, Mo 0.05, Al 0.04, Ti O.04, } \\
\text { Zr 0.04 }\end{array}$ & High pressure turbine discs and blade retainers. \\
\hline CMSX2-10 (single crystal alloys) ...... & 0.67 & $\begin{array}{l}\text { Cr 0.08, Co 0.05, Mo 0.01, Al 0.06, Ti 0.01, } \\
\text { W 0.08, Ta } 0.06\end{array}$ & Turbine blades. \\
\hline FT750DC. & 0.67 & $\mathrm{Cr} 0.20, \mathrm{Al} 0.02, \mathrm{Ti} 0.02, \mathrm{~W} 0.04, \mathrm{~B}$ trace & Creep resistant, power plant applications. \\
\hline 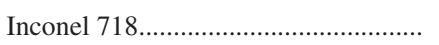 & 0.53 & Cr 0.19 , Co 0.01 , Mo 0.03 , Ti 0.01, Nb 0.04 & Jet engine, gas turbine operations. \\
\hline Hastelloy G-50 .................................... & 0.50 & $\begin{array}{l}\text { Cr 0.20, Co 0.03, Cu 0.01, Mo 0.09, Mn, } \\
\text { 0.01, Si 0.01, W } 0.01\end{array}$ & $\begin{array}{l}\text { Used in oil production applications, resists corrosion from } \\
\text { sour gas environments. }\end{array}$ \\
\hline 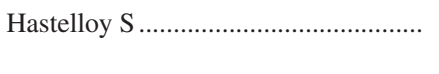 & 0.62 & Cr 0.16, Co 0.02, Mo 0.15, Mn 0.01, W trace & $\begin{array}{l}\text { Used extensively as seal rings in gas turbine engines. Its low } \\
\text { thermal expansion coefficient is also important. }\end{array}$ \\
\hline 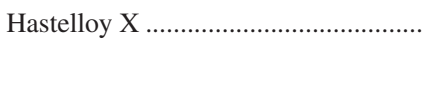 & 0.47 & $\begin{array}{l}\text { Cr 0.22, Co 0.02, Mo 0.09, Mn 0.01, Si 0.01, } \\
\text { W 0.01 }\end{array}$ & $\begin{array}{l}\text { Furnace applications (rolls, trays), jet engine tailpipes, af- } \\
\text { terburner components, turbine blades, nozzle vanes, cabin } \\
\text { heaters, gas turbine combustion cans, and ducting. }\end{array}$ \\
\hline $\begin{array}{l}\text { Inconel MA758 (oxide dispersion } \\
\text { strengthened) }\end{array}$ & 0.77 & $\mathrm{Cr} 0.20, \mathrm{Y}_{2} \mathrm{O}_{3} 0.1$ & $\begin{array}{l}\text { Used for a range of high performance thermal processing } \\
\text { applications. }\end{array}$ \\
\hline 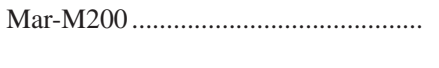 & 0.60 & $\begin{array}{l}\text { Cr 0.09, Co 0.10, Al 0.05, Ti 0.02, W 0.12, } \\
\text { Nb } 0.01\end{array}$ & Single crystal turbine airfoils. \\
\hline Waspaloy ......... & 0.58 & Cr 0.20, Co 0.14, Mo 0.04, Al 0.01, Ti 0.03 & $\begin{array}{l}\text { Used for numerous rotating and nonrotating turbine engine } \\
\text { components. }\end{array}$ \\
\hline Udimet $500 \ldots$. & 0.54 & Cr 0.18, Co 0.19, Mo 0.04, Al 0.03, Ti 0.03 & Turbine blades. \\
\hline 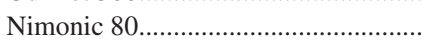 & 0.76 & Cr $0.20, \mathrm{Al} 0.01, \mathrm{Ti} 0.02$ & Turbine blades. \\
\hline 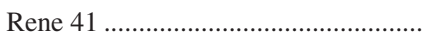 & 0.55 & Cr 0. 19, Co 0.11, Mo 0.10, Al 0.02, Ti 0.03 & Jet engines. \\
\hline 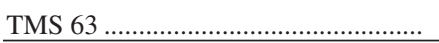 & 0.71 & Cr 0.07, Mo 0.07, Al 0.06, Ta 0.08 & Single crystal turbine blades. \\
\hline
\end{tabular}

Astroloy is a trademark of General Electric Company.

CMSX-2 is a registered trademark of Cannon-Muskegon Corporation.

Hastelloy, and Waspaloy are registered trademarks of Haynes International, Inc.

Inconel, Nimonic, and Udimet are registered trademarks of Special Metals Corporation.

MAR-M200 is a trademark of Martin Marietta Corporation.

Rene is a registered trademark of Teledyne Allvac Company. 
$\mathrm{t}$ to $19,500 \mathrm{t}$ of nickel per year, with an average of 14,900 $\mathrm{t}$ [calculated from data provided by Kelly and Matos (2006)].

\section{PRICES}

Figure 14 shows price indices (with 1955 as base year) for nickel and copper, for the period 1955 through $2005^{4}$. The period indices were constructed from the annual average prices (reported by the London Metal Exchange) of the commodities.

There are two fairly distinct regions in figure 14. For the first period (1955 through 1973), the price indices for nickel and copper are relatively flat with relatively low volatility ${ }^{5}$. The index averages \pm standard deviation for the period 1955-73 for each element were: nickel, $1.39 \pm 0.41$ (volatility $=29$ percent $)$; copper, $1.04 \pm 0.27$ (volatility $=$ 26 percent).

In 1973, the dollar was decoupled from gold. The result was an increase in both the price levels and the volatility for nickel and copper. For the period 1974 through 2005, the index averages \pm standard deviation for the metals were: nickel, $4.82 \pm 2.07$ (a price level increase of 247 percent, and a volatility increase of 47 percent); copper, $2.47 \pm 0.69$

${ }^{4}$ The index for commodity " $\mathrm{c}$ " is defined as nominal annual average price for commodity "c' in year " $y$ " divided by the nominal annual average price for commodity "c" in 1955 . The base year 1955 was selected because it was the beginning year in the data series. The reason for constructing price indices, rather than directly plotting prices, was to facilitate comparison by representing the selected commodities at the same scale.

${ }^{5}$ Volatility in prices, for the selected period, is represented here as the standard deviation (of either the price, or price-index series) for the period, divided by the average for the period, and is expressed as the percentage of the average. (a price level increase of 137 percent, and a volatility increase of 9 percent).

Figure 15 shows the history of average annual nickel metal prices from 1900 through 2007. Prices are presented in nominal and constant ${ }^{6}$ (1998) dollars per kilogram. For the 90-year period, 1915 through 2005, constant-dollar nickel prices were relatively steady at about $\$ 9.10$ per year, which indicates a predictable market for the period. There was a notable price spike in 1988,89 , two years where there was record demand for nickel and where labor and contract disputes severely restricted supply. After 2005, and continuing through 2007, constant-dollar nickel prices have escalated well above the ${ }_{1998} \$ 9.10$ per year level. This price spike was driven by high demand for stainless steel in China and the United States and supply-tightening strikes in several producing regions.

Stainless steel is both the largest product end use for nickel and the largest source for nickel units from scrap. Because nickel is one of the most expensive elements in stainless steel, it is not surprising that stainless-steel scrap prices closely reflect the rise and fall of nickel metal prices. Figure 16 compares monthly prices for a common stainlesssteel scrap (18 weight percent chromium, 8 weight percent nickel) with London Metal Exchange nickel metal prices for the period March 1997 through February 2007.

By comparing selected peaks and valleys for the indices presented in figure 16, one can see that AISI type 304 stain-

${ }^{6}$ Constant (1998) dollars were determined by dividing nominal dollars in year " $y$ " by the consumer price index number (as reported by the Bureau of Labor Statistics, Department of Commerce), for year "y." The consumer price index was selected over other indices (which, arguably, might be better suited for commodity pricing studies) owing to its common acceptance.

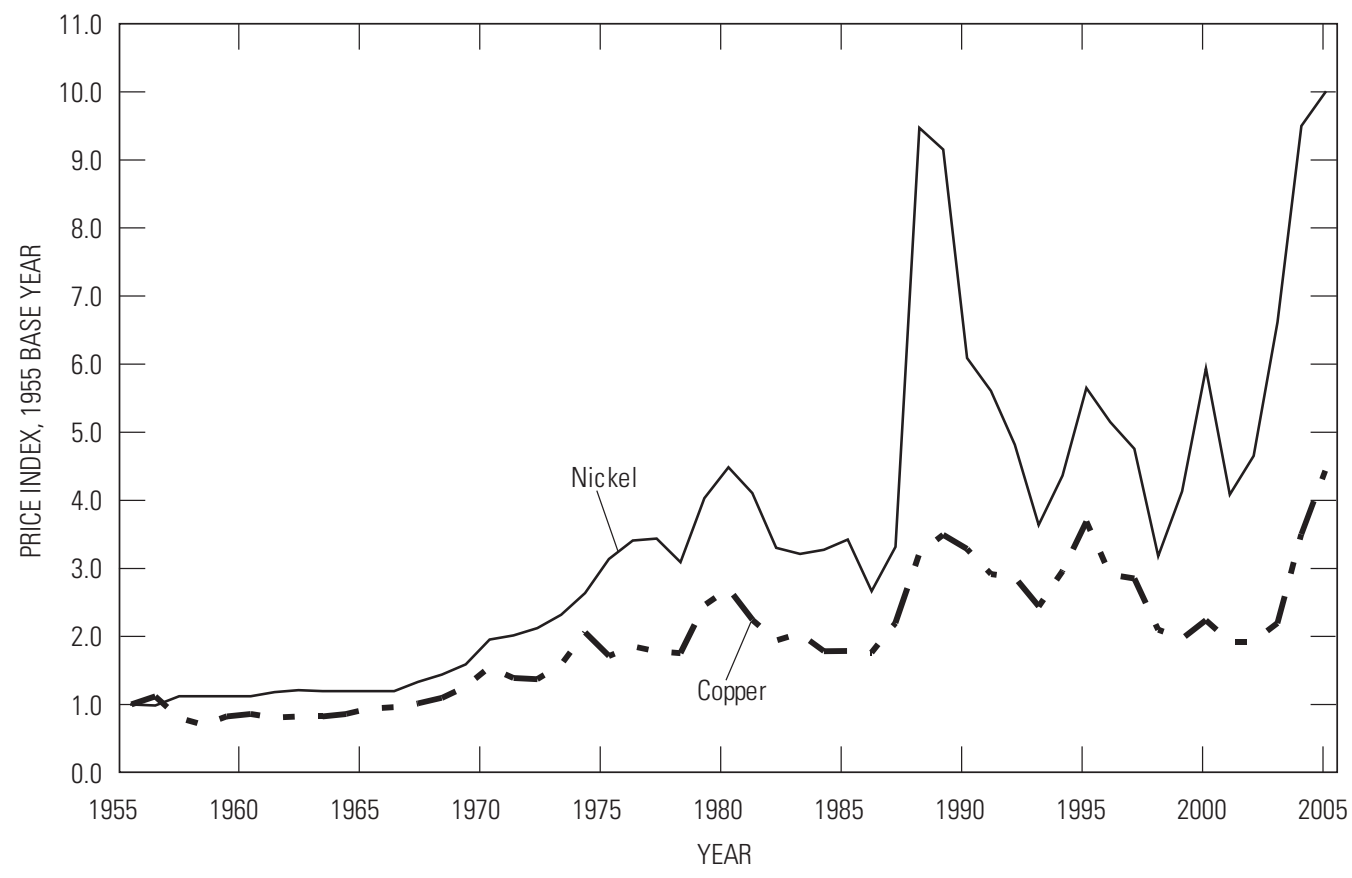

Figure 14. Chart showing indexed price comparisons for nickel and copper, from 1955 through 2005. Values are an index of metal price in year "y," divided by the metal price in 1955 (index base year). Prices are the average of cash settlements for each month taken on the end of the last day of the month.

Source: London Metal Exchange, 2007. 


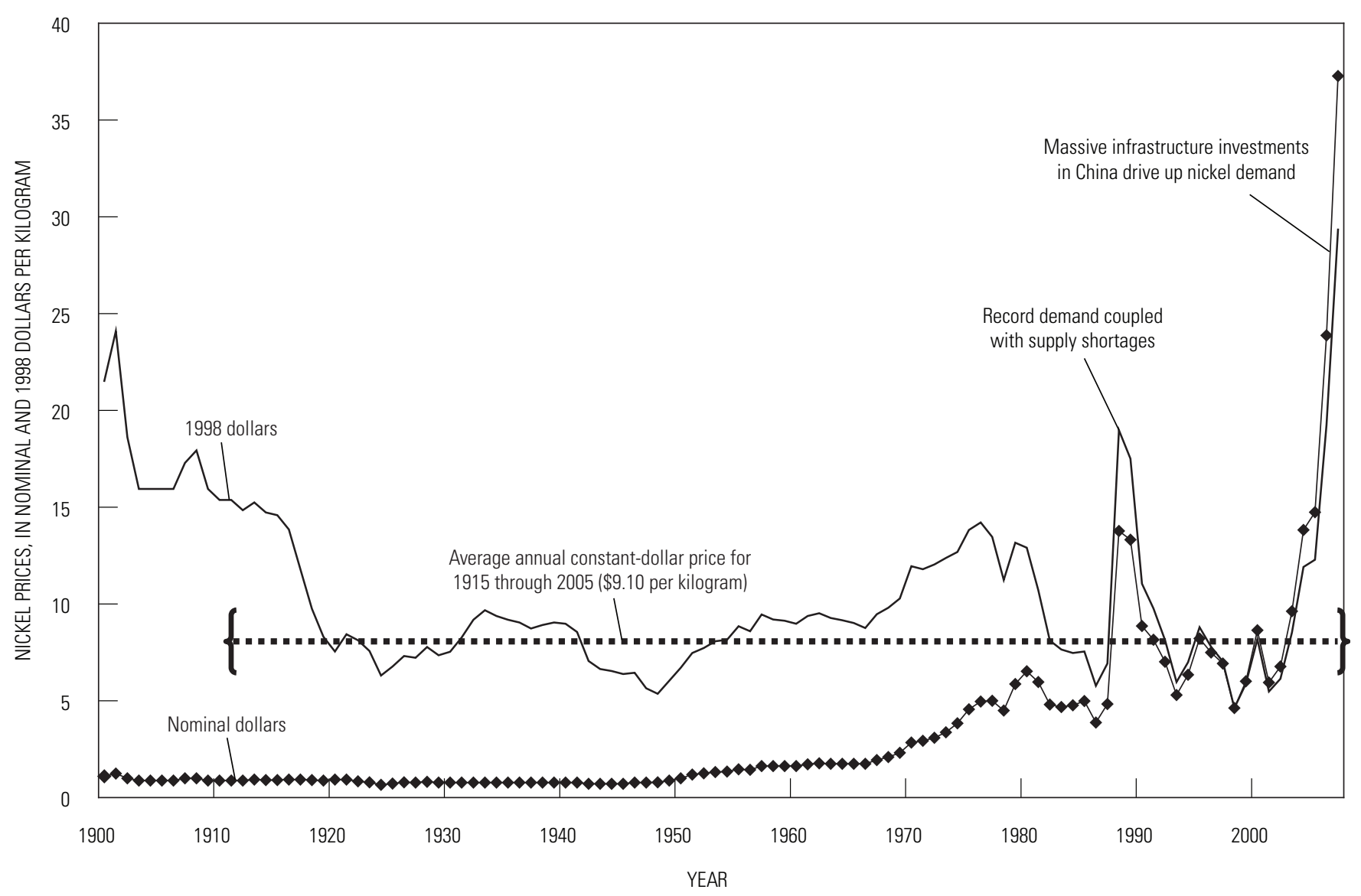

Figure 15. Chart showing nickel prices by year, 1900 through 2007. Values are in dollars (nominal and constant) per kilogram metal. Sources: U.S. Geological Survey (1999) and London Metal Exchange (2007).

less-steel scrap price changes historically lag nickel metal price changes by 2 to 5 months. For the period from March 1997 through June 2003, the average for the index of metal prices was 0.47 . For the subsequent period from July 2003 through June 2006, the average for the index of nickel metal prices was 1.04. From July 2006 through February 2007, the price indices for both have trended upwards beyond the previous two periods.

\section{SOURCES AND DISPOSITION OF NICKEL SCRAP}

Because nickel has highly sought after properties in production technologies and end uses and is relatively scarce, significant amounts of nickel-containing scrap materials have sufficient value to overcome the cost of collecting and reprocessing them. Recycling of nickel-containing scrap is a dynamic business. Nickel and nickel-containing ferrous and nonferrous alloys provide the bulk of nickel scrap. During primary operations and intermediate manufacturing, scrap is generated in forms such as borings, clippings, cuttings, and turnings. The scrap, referred to as new scrap, is readily col- lected and soon is returned to furnaces in primary operations facilities. Post-consumer scrap (old scrap) must first be separated from the other parts of assembled products; for example, high nickel-content turbine blades are separated from light metal airframes. The old scrap is then processed into material of similar composition and smaller and more uniformly sized shapes for ease of handling and melting.

The remainder of recycled nickel originates from sources such as mixed dusts collected in pollution-control devices, sludge from pickling solutions in the metals industry and water-treatment operations, various types of slag, and other residues from metallurgical operations, spent electrolytes from electroplating, and spent catalysts. Rechargeable batteries, many of which contain nickel, have grown in use with the proliferation of electronic devices and other products. Nickel is a major component of cell mass in such batteries (22 percent for nickel-cadmium, and 37 percent for nickel-metal hydride) (Vangheluwe and others, 2005).

Spent nickel-containing batteries are collected by several entities; however, they primarily are collected through a public service program run by the Rechargeable Battery Recycling Corporation (RBRC), which facilitates the flow of spent 


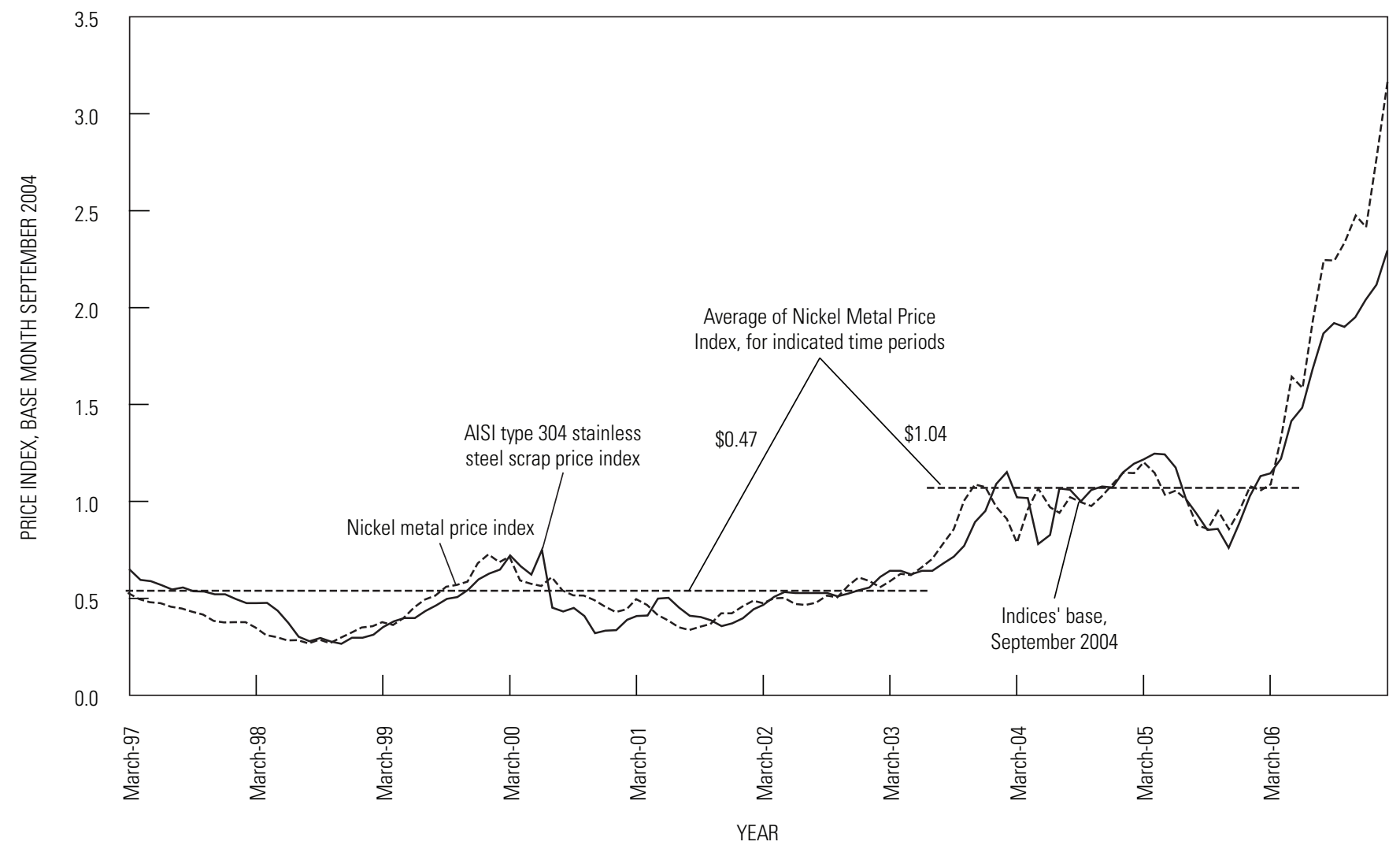

Figure 16. Chart showing indices of the average monthly prices for AISI type 304 stainless-steel scrap and nickel metal, March 1997 through February 2007. The basis for the indices is September 2004. AISI type 304 stainless-steel scrap is defined as solids and clips, broker price, at Chicago, United States. Sources: AISI type 304 stainless-steel scrap prices: American Metal Market (2007); nickel prices: London Metal Exchange (2007).

batteries from generators directly to the only approved and permitted domestic smelter these batteries (Warren, 2006). Whatever stock RBRC cannot direct to a domestic recycler, they export. Table 8 shows the annual amounts of nickel-containing batteries recycled from 1999 through 2005.

The U.S. Geological Survey calculates that battery scrap available for recycling in 2004 contained about 9,090 $\mathrm{t}$ of nickel and that about $440 \mathrm{t}$ of nickel was recovered as ferronickel from nickel-containing battery scrap that was processed. Therefore, the recovery rate for nickel from U.S.generated battery scrap was less than 5 percent, which is much lower than the recovery rate for other types of nickel scrap. In 2004, about 52 percent of the nickel contained in U.S.-produced nickel-containing products came from nickel-containing scrap, of which 88 percent was old scrap and 12 percent was new scrap.

\section{OLD SCRAP}

Old scrap is a product of obsolescence and becomes a source of nickel units for primary operations that manufacture nickel-containing products; however, not all of the material that becomes obsolete is recycled, and that which eventually is recycled is not necessarily recycled immediately. For a given year, scrap that is reported as recycled, or as imports and exports, or as part of a stock change should be assumed to be recycled or at least available for near-term recycling. Some of the old scrap resource (sometimes referred to as hibernating scrap) remains in place pending sufficient economic incentive to collect and process it. Another part of the old scrap resource will remain in landfills unless and until economic conditions justify the mining of the landfill "deposit." Finally, material is lost to dissipation (corrosion and wear loss, fertilizers, and paints) and cannot be recovered. For most nickel-containing materials, dissipative losses are minimal. What is actually consumed by the users of nickel-containing product is the economic utility of the material as originally placed in service. Nickel-containing materials are recycled ${ }^{7}$ and returned to service with new utility.

\section{OLD SCRAP GENERATED}

In order to estimate the amount of nickel contained in old scrap generated (appendix), one must have the following

${ }^{7}$ In this report, recycling means recovered and remelted. Nickel recovery from processes such as remanufacturing, which restores economic utility without remelting, is not considered herein. 
Table 8. Spent nickel-containing batteries processed by the Rechargeable Battery Recycling Corporation, the International Metals Reclamation Co. (Inmetco), and Kinsbursky, from 1999 through 2005.

[Measured in metric tons. Sources: Rydh and Svärd (2003); Madani (2003); Vangheluwe and others (2005); D.R. Wilburn (U.S. Geological Survey, oral commun., 2007)]

\begin{tabular}{|c|c|c|c|c|c|c|c|c|}
\hline \multirow{2}{*}{ Battery type } & \multirow{2}{*}{$\begin{array}{c}1999, \\
\text { gross }\end{array}$} & \multirow{2}{*}{$\begin{array}{c}2000, \\
\text { gross }\end{array}$} & \multirow{2}{*}{$\begin{array}{l}2001, \\
\text { gross }\end{array}$} & \multirow{2}{*}{$\begin{array}{l}2002, \\
\text { gross }\end{array}$} & \multirow{2}{*}{$\begin{array}{l}2003, \\
\text { gross }\end{array}$} & \multicolumn{2}{|c|}{2004} & \multirow{2}{*}{$\begin{array}{c}2005 \\
\text { gross } \\
\end{array}$} \\
\hline & & & & & & Gross & Nickel & \\
\hline 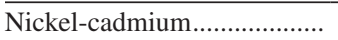 & 1,130 & 1,240 & 1,270 & 1,350 & 1,710 & 1,690 & 372 & 1,750 \\
\hline 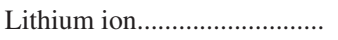 & & 1 & 71 & 74 & 104 & 128 & 1 & 174 \\
\hline Nickel-metal hydride.............. & & 27 & 105 & 130 & 109 & 184 & 68 & 224 \\
\hline 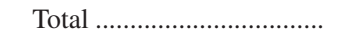 & 1,130 & 1,270 & 1,440 & 1,560 & 1,920 & 2,010 & 441 & 2,150 \\
\hline Percentage increase. & & 12.3 & 13.8 & 7.9 & 23.2 & 4.5 & & 7.0 \\
\hline
\end{tabular}

information: the average nickel content of various types of nickel-containing scrap; flow distributions (from domestic manufacturing and imports or exports of semifinished and finished materials) for nickel-containing materials to enduse sectors; and the average service life of the materials.

The Nickel Institute used information from market suppliers and other experts to create an estimate of the partitions for nickel among four end-use market categories: architectural, building and construction (20 percent); commercial goods (29 percent); industrial goods (27 percent); and transportation goods (24 percent) (Nickel Institute, 2003, a-d). The Nickel Institute further divided these categories into subcategories and provided an estimate of the average service life of nickel products within the subcategories. Table 9 shows those subcategories, estimated servicelife data, and the U.S. Geological Survey's estimate of the amount of nickel that was contained in the scrap that each subcategory theoretically contributed to the entire stock of old scrap in 2004.

In 2004, the nickel product reservoir generated 247,000 $\mathrm{t}$ of nickel (contained in old scrap, batteries, and dissipated chemicals) that theoretically had reached the end of its economic utility. The $247,000 \mathrm{t}$ of nickel contained in old scrap came from: the architectural, building and construction sector; $37,000 \mathrm{t}$; the commercial sector, 73,000 t; the industrial sector, 64,000 t; the transportation sector, 63,000 t; batteries, 9,000 t; and dissipated chemicals, 2,000 t.

\section{OLD SCRAP UNRECOVERED}

Old scrap unrecovered in a particular year might not be entirely lost. There are several possibilities to account for its unrecovered status. It could be abandoned in place (hibernating) pending suitable economic incentives (higher scrap prices) to warrant collection and processing. It might have been collected and deposited in landfills, which would also conserve it for a time when better prices prevail. It might have been dissipated (dispersed or scattered) during use-for example, nickel contained in unrecycled paints and fertilizers. If that were the case, it would be exceptionally difficult and costly to recycle or recover the metal. Lastly, if the estimate of old scrap generated is incorrect, then the old scrap may exist in greater or lesser quantities depending upon the nature of the error in the estimate.

In previous recycling reports, the U.S. Geological Survey estimated and reported old scrap unrecovered without adjustments for the possibilities just described. For this report, an estimate of nickel contained in the scrap flow to landfills in 2004 is based on information developed and reported by the Nickel Institute (Nickel Institute, 2003a-e) (fig. 1).

The flow of nickel to landfills is part of old scrap unrecovered. The remainder is old scrap unaccounted for $(65,000 \mathrm{t}$ of nickel). The landfill stock can be treated as a future resource that generated zero flow in 2004 owing to insufficient price incentives.

\section{OLD SCRAP RECOVERED AND USED}

The nickel contained in old scrap recovered and used is the sum of old scrap generated $(247,000 \mathrm{t})$, less the nickel contained in old scrap unrecovered $(123,000 \mathrm{t})-124,000 \mathrm{t}$ of nickel (about 50 percent of old scrap generated) in 2004.

\section{OLD SCRAP SUPPLY}

As shown in figure 1, old scrap theoretical supply for the United States in 2004 was 267,000 t of nickel. Old scrap actual supply was 144,000 t of nickel—old scrap theoretical supply less old scrap unrecovered (123,000 t of nickel). Actual old scrap supply of nickel was distributed between domestic old scrap consumption $(95,000 \mathrm{t}$, or 66 percent of actual supply) and old scrap exports $(49,000$ t, or 34 percent of the actual supply).

\section{NEW SCRAP}

Scrap that is generated by secondary manufacturers is called "new" or "prompt" scrap (appendix) and includes borings, clippings, cuttings, filings, and turnings that result from the reshaping of manufactured products. While this report treats the flow of new scrap from downstream manufacturers to primary operations as certain and 100 percent recoverable, some refinements to this flow might be possible with better data. 
Table 9. Scrap generation from various end uses in 2004.

[Values are in metric tons (t) contained nickel, unless otherwise specified. Source: Rydh and Svärd (2003); Madani (2003); Nickel Institute (2003e); Kuck (2005); Vangheluwe and others (2005); Kelly and Matos (2006); D.R. Wilburn (U.S. Geological Survey, oral commun., 2007)]

\begin{tabular}{|c|c|c|c|c|c|c|c|c|c|}
\hline End-use category & $\begin{array}{l}\text { Fraction of } \\
\text { total nickel } \\
\text { placed in } \\
\text { service }\end{array}$ & $\begin{array}{l}\text { Average } \\
\text { life (in } \\
\text { years) }\end{array}$ & $\begin{array}{l}\text { Total nickel } \\
\text { placed-in- } \\
\text { service in } \\
\text { year 2004- } \\
\text { life }\end{array}$ & $\begin{array}{l}\text { Nickel } \\
\text { contained in } \\
\text { generated } \\
\text { scrap }\end{array}$ & $\begin{array}{l}\text { Nickel } \\
\text { contained in } \\
\text { recovered } \\
\text { scrap }\end{array}$ & $\begin{array}{l}\text { Nickel } \\
\text { going to } \\
\text { nickel } \\
\text { loop }\end{array}$ & $\begin{array}{l}\text { Nickel } \\
\text { going } \\
\text { to steel } \\
\text { loop }\end{array}$ & $\begin{array}{l}\text { Nickel } \\
\text { going to } \\
\text { copper } \\
\text { loop }\end{array}$ & $\begin{array}{l}\text { Nickel } \\
\text { going to } \\
\text { landfills }\end{array}$ \\
\hline \multicolumn{10}{|c|}{ Architectural, building, and construction } \\
\hline 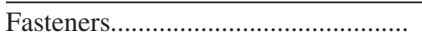 & 0.048 & 30 & 192,000 & 9,220 & 6,450 & & 6,450 & & 2,760 \\
\hline Sinks and baths ...... & 0.026 & 30 & 192,000 & 4,990 & 3,490 & & 3,490 & & 1,500 \\
\hline Wire, cable, rope & 0.026 & 30 & 192,000 & 4,990 & 3,490 & & 3,490 & & 1,500 \\
\hline Street furniture ....... & 0.022 & 30 & 192,000 & 4,220 & 2,960 & & 2,960 & & 1,270 \\
\hline 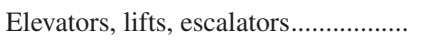 & 0.02 & 30 & 192,000 & 3,840 & 2,690 & & 2,690 & & 1,150 \\
\hline Space heating ........ & 0.02 & 30 & 192,000 & 3,840 & 2,690 & & 2,690 & & 1,150 \\
\hline 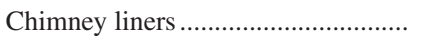 & 0.016 & 30 & 192,000 & 3,070 & 2,150 & & 2,150 & & 920 \\
\hline Other & 0.016 & 30 & 192,000 & 3,070 & 2,150 & & 2,150 & & 920 \\
\hline 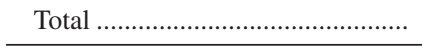 & 0.194 & & & 37,300 & 26,100 & & 26,100 & & 11,210 \\
\hline \multicolumn{10}{|c|}{ Commercial and general } \\
\hline 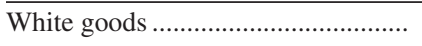 & 0.093 & 15 & 271,000 & 25,200 & 24,500 & & 23,900 & 500 & 760 \\
\hline 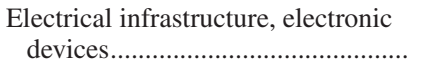 & 0.075 & 10 & 300,000 & 22,500 & 6,750 & 2,250 & 4,050 & 450 & 15,800 \\
\hline 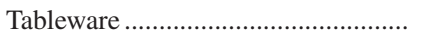 & 0.038 & 30 & 192,000 & 7,300 & 4,820 & & 4,820 & & 2,480 \\
\hline 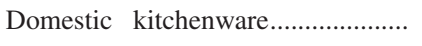 & 0.032 & 25 & 219,000 & 7,010 & 5,260 & & 5,260 & & 1,750 \\
\hline Commercial kitchenware ..................... & 0.17 & 20 & 245,000 & 4,170 & 3,750 & & 3,540 & 210 & 420 \\
\hline 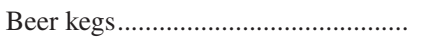 & 0.012 & 15 & 271,000 & 3,250 & 3,220 & & 3,220 & & 30 \\
\hline 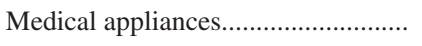 & 0.009 & 20 & 245,000 & 2,210 & 1,320 & & 1,320 & & 880 \\
\hline Coinage & 0.006 & 25 & 219,000 & 1,310 & 1,250 & & 120 & 1,130 & 70 \\
\hline 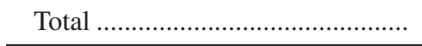 & 0.282 & & & 72,900 & 50,800 & 2,250 & 46,300 & 2,290 & 22,100 \\
\hline \multicolumn{10}{|c|}{ Industrial machinery and equipment } \\
\hline 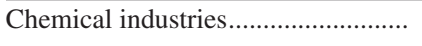 & 0.086 & 25 & 219,000 & 18,800 & 18,700 & 15,100 & 3,580 & & 190 \\
\hline 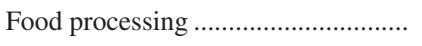 & 0.046 & 25 & 219,000 & 10,100 & 9,570 & 8,060 & 1,510 & & 500 \\
\hline 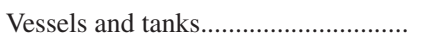 & 0.043 & 25 & 219,000 & 9,240 & 8,950 & 7,530 & 1,410 & & 470 \\
\hline 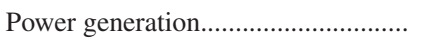 & 0.032 & 20 & 245,000 & 7,840 & 7,800 & 6,270 & 1,490 & & 40 \\
\hline 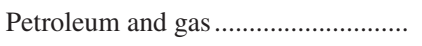 & 0.022 & 20 & 245,000 & 5,390 & 5,340 & 4,310 & 1,020 & & 50 \\
\hline Other & 0.04 & 10 & 300,000 & 12,000 & 9,000 & 6,000 & 2,640 & 360 & 3,000 \\
\hline 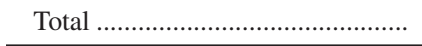 & 0.269 & & & 63,600 & 59,300 & 47,200 & 11,700 & 360 & 4,260 \\
\hline \multicolumn{10}{|c|}{ Transportation equipment } \\
\hline 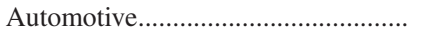 & 0.149 & 12 & 289,000 & 43,100 & 34,500 & 17,200 & 16,400 & 860 & 8,610 \\
\hline 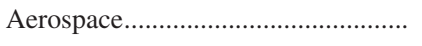 & 0.038 & 15 & 271,000 & 10,300 & 10,200 & 8,750 & 1,440 & & 100 \\
\hline Marine ........ & 0.019 & 35 & 163,000 & 3,100 & 2,940 & 2,320 & 560 & 60 & 150 \\
\hline 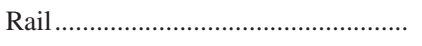 & 0.012 & 35 & 163,000 & 1,960 & 1,860 & 1,470 & 350 & 40 & 100 \\
\hline Other & 0.022 & 30 & 192,000 & 4,220 & 2,960 & & 2,960 & & 1,270 \\
\hline 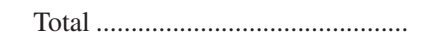 & 0.24 & & & 62,600 & 52,400 & 29,800 & 21,700 & 960 & 10,200 \\
\hline Total, all categories ${ }^{1}$........................ & 0.985 & & & 236,000 & 189,000 & 79,300 & 106,000 & 3,610 & 47,800 \\
\hline 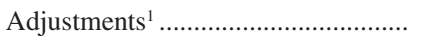 & & & & 110,002 & & & & & 110,003 \\
\hline 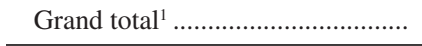 & & & & 247,000 & & & & & 58,400 \\
\hline
\end{tabular}

${ }^{1}$ Independently rounded to three significant figures.

${ }^{2}$ Batteries (9,090 $t$ of nickel), plus chemicals (1,950 t of nickel).

${ }^{3}$ Batteries (8,644 t of nickel), plus chemicals (1,950 t of nickel). 
Small semifabrication facilities may not have agreements or the means to move generated scrap back to primary operating facilities. In such cases, a fraction of new scrap generated might not make it directly to new scrap consumed but rather leave the direct flow and travel back through the old scrap flow. That fraction would be downgraded from new scrap to old scrap.

Another category of new scrap is scrap associated with auxiliary processing, such as pickling, where nickel can be recovered from nickel-containing solutions with special processing. The nickel recovered from these solutions does not go to primary operating facilities as metallic scrap does but rather returns as one of the products associated with carriers of primary nickel. For example, pickle liquors may become nickel-containing chemicals, and battery wastes may become ferronickel.

In 2004, 13,000 t of nickel contained in new scrap was consumed in the domestic production of nickel-containing products. Based on U.S. scrap consumption, the new-to-oldscrap ratio was 12:88. In 2004, semifabrication processes generated new scrap amounting to 5.4 percent of total material processed.

\section{INFRASTRUCTURE OF THE NICKEL SCRAP INDUSTRY}

Nickel (in alloys and superalloys) is recycled through mixed-scrap processing. Stainless-steel scrap containing nickel is highly recyclable and typically comprises about 60 percent of a new batch of stainless steel. Stainless-steel scrap is more valuable than iron and steel scrap, and scrap dealers compete for the supply. Examples of purchasers of scrap metal are brokers, foundries, mills, mini-mills, peddlers, and scrap processors. Brokers act as agents for others in negotiating contracts, purchases, and sales and most often do not take physical possession of scrap. Scrap peddlers, who purchase scrap metal and resell it to the scrap processors, may have industrial accounts or may search for scrap metal. Scrap processors (dealers and recyclers) collect, sort, package, and prepare for shipping and eventually sell the scrap metal to foundries, mills, mini-mills, and other purchasers. Most processors handle ferrous and nonferrous metals. The equipment used by the scrap processors can include: baling presses, conveyors, cranes, magnets, scales, shears, shredders, sorting systems, storage containers, and trucks (Internal Revenue Service, 1999). Figure 17 shows a sorting scheme for separating stainless steels, nickel alloys and superalloys from mixed scrap.

In 2004, 866,000 t of stainless-steel scrap was received by U.S. manufacturers, 288,000 $t$ of home scrap was produced, and 1,180,000 $\mathrm{t}$ was eventually used (Fenton, 2005). Special alloys are usually recycled as the same special alloy whenever possible (Nickel Institute, 2003e). In 2004, 9,780 $\mathrm{t}$ of nickel contained in nickel and other nickel-containing nonferrous metal alloys was recovered from purchased scrap (Kuck, 2005).

Nickel alloys also are used in industrial processes requiring catalytic assistance-for example, in petrochemical processing (cracking). Examples of typical spent petroleum cracking catalysts are listed in table 10.

Nickel alloys also are used for food processing (fat hydrogenation). Raney nickel is an example of a hydrogenation catalyst of long standing (developed in 1926). By mass, it contains about 90 percent nickel and 10 percent aluminum (Chemical and Engineering News, 2003). Spent hydrogenation catalysts can contain as much as 50 percent fat before recycling (Nasir, 2001).

Other materials available for recycling include nickelcontaining batteries, drosses, dusts, filter cakes, grindings, electrodes, metal-rich solutions, pickle liquors, sludges, and turnings (Queneau, 2005). Table 11 lists some of the principal U.S. processors of these materials.

\section{NICKEL SCRAP TRADE}

The United States was a net exporter of nickel contained in nickel waste and scrap $(5,000 \mathrm{t})$ and in stainlesssteel scrap (25,000 t) in 2004 (table 12). Canada was the principal importer of U.S. nickel contained in nickel wastes ( $8,000 \mathrm{t}$ net, or about 80 percent of total U.S. exports), and China was the largest importer of U.S. nickel contained in stainless-steel scrap $(12,000 \mathrm{t}$ net, or about 33 percent of total U.S. exports). France, Germany, and the United Kingdom provided the bulk of U.S. imports of nickel contained in nickel waste (about 1,000 t each), and part of U.S. exports of such nickel goes to Scandinavia; the remainder went to east Asia and Australia. In 2004, Finland was the largest importer of nickel contained in U.S. stainless-steel scrap $(5,400 \mathrm{t}$, or about 70 percent of the total of such European imports from the United States), and Asian countries other than China (Republic of Korea, Taiwan, and India) imported about 12,000 t of nickel contained in U.S. stainless-steel scrap (Kuck, 2005).

\section{SUMMARY AND OUTLOOK}

In 2004, world demand for primary nickel was $1,050,000 \mathrm{t}$, which was slightly less than the 2003 record high demand of 1,060,000 $t$ (International Nickel Study Group, 2005). Refinery production also increased—rising to $1,260,000 \mathrm{t}$ in 2004 from $1,220,000 \mathrm{t}$ for 2003 , which created a global surplus of about 21,000 $\mathrm{t}$ of primary nickel. In 2004, rising energy and refining costs led, at least in part, to a 44-percent increase of the London Metal Exchange average annual nickel cash price over that of 2003. On the demand side, in 2004, China increased its consumption 


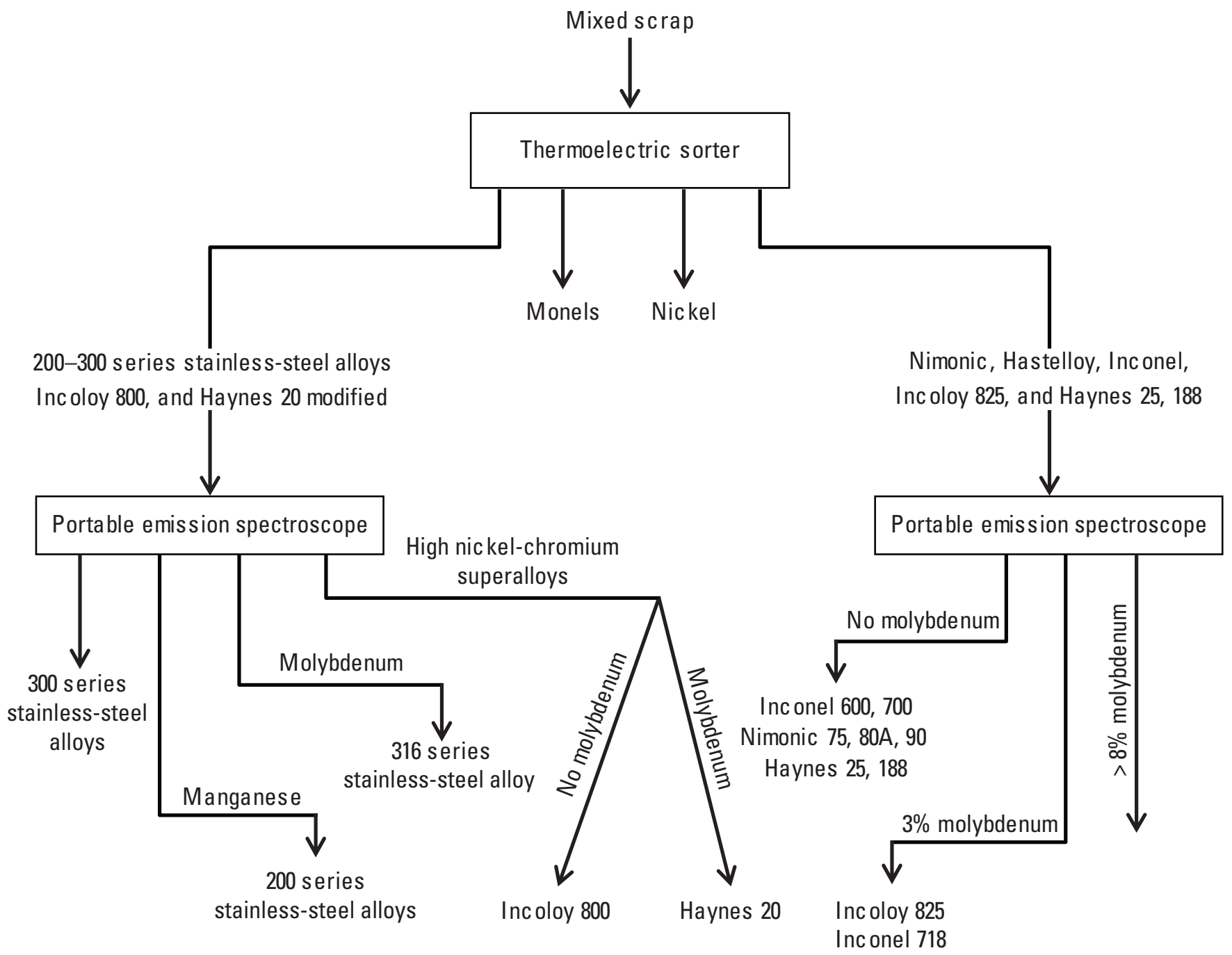

Figure 17. Diagram showing the process flow for separating stainless steels, nickel alloys, and superalloys from mixed scrap. Hastelloy is a registered trademark of Haynes International, Inc. Inconel, Nimonic, and Udimet are registered trademarks of Special Metals Corporation. Incoloy is a registered trademark of Inco Alloys International Inc. The details of how these alloys differ from one another can be seen in tables 3 and 5-7. Source: ASM International (1998).

of nickel to $151,000 \mathrm{t}$, which was close to a 250 percent increase over 1999 levels of consumption (Kuck, 2005). World demand and prices for austenitic stainless-steel scrap generally correlate with nickel prices, as shown in figures 16 and 18. From 1999 through 2005, scrap availability increased as the price of nickel increased (Terörde, 2006).

From 1990 through 2005, the growth in world stainlesssteel production averaged 8.4 percent per year, and the use of purchased scrap grew at 14.5 percent per year (Terörde, 2006). For the Western World, the percentage of scrap used to make new stainless steel is anticipated to remain around 45 percent because additions to scrap supply (normally expected from higher prices) will be offset by increased Chinese demand for scrap, which grew at 14.5 percent per year between 2002 and 2005 (International Stainless Steel Forum, 2006b-d).
Blended scrap is becoming more acceptable to operators of metallurgical facilities, provided that scrap quality standards be maintained and that the price of the blend (plus transportation costs) is less than the delivered price of equivalent ferronickel. Payment terms also are an important consideration. The practice of blending is expected to become more widespread in the future. The evolution of and improvements to scrap collection systems will help meet future scrap demand. The modern scrapyard has become much more than a combined collection point and storage area. The scrap processing facility, which is the next step in the collection chain, also has changed significantly since the 1960s. Most of these processing facilities ship directly to the steel mills. Cleanliness of the scrap (that is, whether scrap is properly segregated) remains an important issue. Since the 1980s, scrap processing has become increasingly specialized 
Table 10. The principal components of spent petroleum catalysts.

[-- means zero. Source: Sackett (2005)]

\begin{tabular}{|c|c|c|c|}
\hline & \multicolumn{3}{|c|}{ Spent catalyst composition } \\
\hline & $\mathrm{HDS}^{1}$ & HDS & Resid $^{2}$ \\
\hline & $\mathrm{Ni} / \mathrm{Mo}$ & Co/Mo & $\mathrm{Ni} / \mathrm{Mo}$ \\
\hline 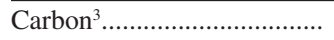 & 5.7 & 5.5 & 19.3 \\
\hline 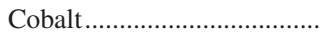 & -- & 2.1 & -- \\
\hline Molybdenum ........................... & 7.4 & 6.3 & 3.8 \\
\hline 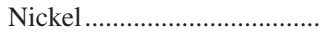 & 2.5 & 0.3 & 4.2 \\
\hline $\mathrm{Oil}^{3}$ & 6.1 & 5.8 & 12.2 \\
\hline (.......................... & 6.7 & 5.6 & 12.9 \\
\hline 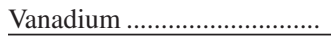 & 0.6 & 0.3 & 9.2 \\
\hline \multicolumn{4}{|c|}{$\begin{array}{l}{ }^{1} \mathrm{HDS} \text { refers to catalysts used for hydrodesulfurization during initial } \\
\text { stages of petroleum refining. }\end{array}$} \\
\hline \multicolumn{4}{|c|}{$\begin{array}{l}{ }^{2} \text { Resid refers to catalysts used for the hydrocracking of residuals during } \\
\text { petroleum refining. }\end{array}$} \\
\hline \multicolumn{4}{|c|}{$\begin{array}{l}{ }^{3} \text { Oil, sulfur, and carbon are the fouling elements that diminish catalyst } \\
\text { activity. }\end{array}$} \\
\hline
\end{tabular}

along lines related directly to customer needs. The continuing growth in stainless-steel production has led to the use of larger and larger tonnages of prepared stainless-steel scrap.

The U.S. collection and recycling program for nickelcadmium (Ni-Cd) and nickel-metal hydride (NiMH) batteries has rapidly expanded since the passage in 1996 of Federal recycling. The program is administered by the Rechargeable Battery Recycling Corporation (RBRC), a nonprofit public-service corporation funded by more than 285 manufacturers and marketers of portable rechargeable batteries and battery-operated products. The program is primarily designed to recycle the more than 75 million small, sealed, rechargeable Ni-Cd batteries sold annually to U.S. and Canadian businesses and consumers for use in cordless products. Four out of five NiCd marketers in North America are RBRC licensees. Almost 25,000 retail outlets or community collection sites in the United States accept spent NiCd batteries. Some 4,500 collection sites in Canada also participate in the RBRC program. The International Metals Reclamation Co. (Inmetco) reclaims the bulk of the collected batteries.

NiMH batteries are largely applied in hybrid vehicles within the transportation sector of the economy. Hybrid vehicle registrations in the United States continue to grow, increasing the demand for battery-grade nickel products. Sales of gasoline-electric hybrid vehicles have risen sharply because of design improvements, a better selection of models, and higher gasoline prices. U.S. registrations for new hybrid passenger vehicles rose to 83,153 in 2004, up 81 percent from 45,943 in 2003. The Toyota Prius accounted for 53,761 of the registrations, or 64 percent of the market in 2004. The second most popular hybrid was the Honda Civic, with 25,586 registrations, or 31 percent of the market. California had the most new hybrid vehiclw registrations-25,021, or 30 percent of the total, followed by Virginia (7 percent) and Washington State (4 percent). The U.S. market for hybrid vehicles has grown 960 percent since their commercial debut in 2000, when new registrations totaled only 7,781 (R.L. Polk and Company, 2005).

\section{REFERENCES CITED}

AK Steel, 2006, Stainless steel comparator: AK Steel Web site at http://www.aksteel.com/pdf/markets_products/stainless/ Stainless_Steel_Comparator.pdf. (Accessed June 19, 2006.)

American Iron and Steel Institute, 2005, Annual statistical report-2004: Washington, D.C., American Iron and Steel Institute, $130 \mathrm{p}$.

American Metal Market, 2007, Database (prices)—Response to special query for period March 1997 through March 2007 for ferrous scrap, stainless, broker, 304 solids, clips, Chicago: American Metal Market Web site at http://amm.com/priorprice/ matprice.asp. (Query requests available by subscription only). (Accessed March 5, 2007.)

ASM International, 1998, Recycling and life-cycle analysis: Article edited by J.C. Bittence, in Metals handbook desk

Table 11. U.S. metallurgical facilities that treat nickel-containing products or wastes to recover nickel.

[Source: Queneau (2005)]

\begin{tabular}{|c|c|c|c|}
\hline Processor & Location & Residue sources & Products \\
\hline Envirite, Inc...... & $\begin{array}{l}\text { York, Pa.; Canton, Ohio; } \\
\text { and Harvey, Ill. }\end{array}$ & Plating-rack strip liquor & Nickel and copper hydroxide \\
\hline Greenville Metals, Inc & Transfer, Pa. & $\begin{array}{l}\text { Scrap, grindings, dust, spills, spatters, } \\
\text { skulls, oily turnings, sludges }\end{array}$ & $\begin{array}{l}\text { Specialty alloy ingot, pig, shot, and } \\
\text { powders }\end{array}$ \\
\hline U.S. Filter, Inc. & St Paul, Minn. & Spent electrodes, nickel baths & Nickel-metal sponge \\
\hline Agmet, Inc.... & Oakwood Village, Ohio & $\begin{array}{l}\text { Catalysts, filter cake, grindings, flue dust, } \\
\text { metal-rich solutions }\end{array}$ & Nickel metal \\
\hline INMETCO, Inc. .......... & Ellwood City, Pa. & $\begin{array}{l}\text { Electric-arc furnace dust, swarf, catalysts, } \\
\text { spent batteries }\end{array}$ & Iron-chromium-nickel ferroalloy \\
\hline Langeloth Metallurgical Company, LLC ............. & Langeloth, Pa. & $\begin{array}{l}\text { Hydrogenation catalysts, electrodes, } \\
\text { nickel solutions }\end{array}$ & Nickel-rich solids for smelting \\
\hline Alpha-Omega Recycling, Inc........ & Longview, Tex. & Nickel-copper filter cakes & Copper-nickel carbonates \\
\hline
\end{tabular}


Table 12. Net U.S. trade in nickel-containing scrap by country in 2004.

[-- means zero. Figures in parentheses are negative numbers. Source: Kuck (2005)]

\begin{tabular}{|c|c|c|c|c|c|c|c|c|}
\hline \multirow[b]{2}{*}{ Country } & \multicolumn{4}{|c|}{ Nickel waste and scrap } & \multicolumn{4}{|c|}{ Stainless steel scrap } \\
\hline & $\begin{array}{c}\text { U.S. } \\
\text { exports to }\end{array}$ & $\begin{array}{c}\text { U.S. } \\
\text { imports from }\end{array}$ & $\begin{array}{l}\text { Net exports } \\
2004\end{array}$ & $\begin{array}{c}\text { Net exports } \\
2003\end{array}$ & $\begin{array}{c}\text { U.S. } \\
\text { exports to }\end{array}$ & $\begin{array}{c}\text { U.S. } \\
\text { imports from }\end{array}$ & $\begin{array}{l}\text { Net exports } \\
2004\end{array}$ & $\begin{array}{c}\text { Net exports } \\
2003\end{array}$ \\
\hline 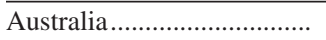 & 114 & 90 & 24 & 43 & 1 & -- & 1 & -- \\
\hline 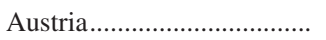 & -- & 5 & (5) & -- & -- & -- & -- & -- \\
\hline 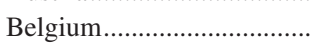 & 47 & 14 & 33 & 71 & 56 & 10 & 46 & 44 \\
\hline 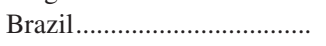 & -- & 78 & (78) & (16) & 20 & 90 & (70) & 53 \\
\hline 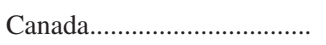 & 9,910 & 1,810 & 8,100 & 5,960 & 1,850 & 7,330 & $(5,480)$ & $(1,480)$ \\
\hline 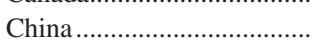 & 65 & 22 & 43 & 69 & 11,800 & 5 & 11,800 & 6,210 \\
\hline 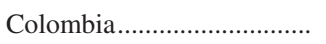 & -- & 2 & (2) & 1 & 4 & 52 & (48) & (7) \\
\hline Dominican Republic ............ & -- & -- & -- & -- & -- & 21 & (21) & (9) \\
\hline 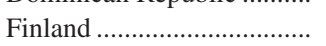 & 243 & -- & 243 & 136 & 5,400 & 8 & 5,400 & 5,770 \\
\hline 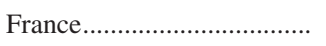 & 32 & 1,090 & $(1,060)$ & $(632)$ & 50 & -- & 50 & -- \\
\hline 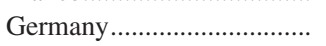 & 203 & 1,390 & $(1,190)$ & $(445)$ & 314 & 1 & 313 & 47 \\
\hline 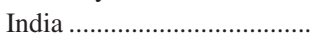 & 20 & -- & 20 & 82 & 1,840 & -- & 1,840 & 858 \\
\hline 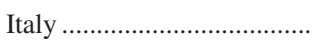 & -- & -- & -- & -- & 11 & -- & 11 & 485 \\
\hline 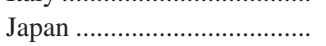 & 353 & 171 & 182 & 397 & 434 & 3 & 431 & 545 \\
\hline Korea, Republic of ................... & 20 & - & 20 & - & 6,670 & - & 6,670 & 6,360 \\
\hline 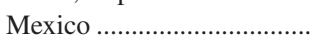 & -- & 169 & (169) & $(55)$ & 238 & 1,970 & $(1,730)$ & $(2,160)$ \\
\hline 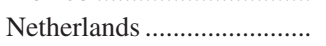 & 46 & 28 & 18 & (8) & 1,000 & 256 & 744 & 1,161 \\
\hline 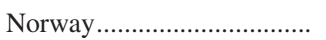 & -- & 22 & (22) & (27) & -- & -- & -- & -- \\
\hline 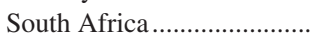 & 30 & -- & 30 & 86 & -- & -- & -- & 2 \\
\hline Spain ............................................ & -- & -- & -- & -- & 696 & -- & 696 & 2,580 \\
\hline Sweden & 250 & -- & 250 & 380 & 3 & -- & 3 & 35 \\
\hline 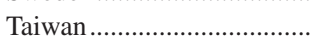 & 24 & -- & 24 & 14 & 3,240 & -- & 3,240 & 9,630 \\
\hline United Kingdom...................... & 790 & 2,000 & $(1,210)$ & $(1,190)$ & 266 & 1 & 265 & 493 \\
\hline 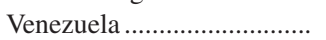 & -- & 76 & (76) & (47) & -- & 367 & (367) & (36) \\
\hline 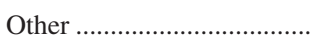 & 271 & 891 & $(620)$ & $(221)$ & 2,920 & 2,770 & 145 & 547 \\
\hline Total .......................................... & 12,400 & 6,970 & 5,550 & 4,600 & 36,800 & 12,000 & 24,800 & 31,100 \\
\hline
\end{tabular}

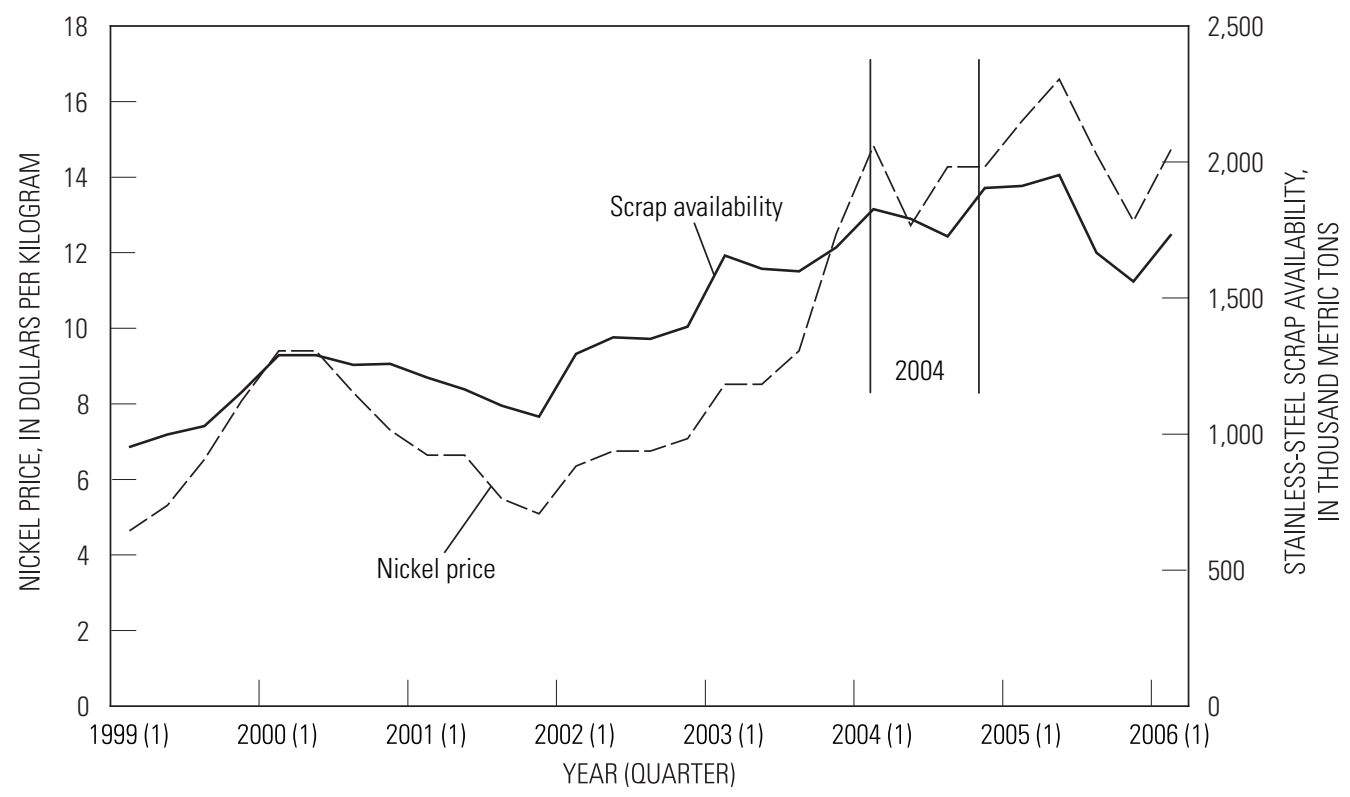

Figure 18. Chart showing nickel prices and scrap availability, by quarter, from 1999 through the first quarter of 2006. Values are for price in dollars per kilogram, for availability in thousand metric tons $(\mathrm{t})$ of scrap. Source: Terörde (2006). 
edition, $2^{\mathrm{d}}$ ed., American Society for Metals International, Materials Park, Ohio, p. 1182-1196. (Also available online for ASM members only at ASM International Web site http://products.asminternational.org/asm/servlet/Navigate.)

Bhadeshia, H.K.D.H., 2003, Nickel based superalloys: Cambridge, United Kingdom, University of Cambridge Web site at http://www.msm.cam.ac.uk/phase-trans/2003/Superalloys/ superalloys.html. (Accessed October 25, 2006.)

Bleiwas, D.I., 1991, Availability of primary nickel in marketeconomy countries-A minerals availabililty appraisal: U.S. Bureau of Mines Information Circular 9276, p. 51-52.

Bowman, Randy, 2006, Superalloys-A primer and history: The Metallurgical Society Web site at http://www.tms.org/ Meetings/Specialty/Superalloys2000/SuperalloysHistory.html. (Accessed October 25, 2006.)

Chemical and Engineering News, 2003, Periodic table, nickel: American Chemical Society Web site at http://pubs.acs.org/ cen/80th/nickel.html. (Accessed September 11, 2007.)

Duncan, R.N., 1995, Electroless nickel-Past, present and futureAn update, in Proceedings, Electroless nickel '95, Fort Mitchell, Ky., November 6-8, 1995: Cincinnati, Ohio, Gardner Publications, Inc., p. 1-1 to 1-14.

e-Funda, 2006, General information on alloy steels: e-Funda Web site at http://efunda.com/materials/alloys/alloy_steels/ alloy.cfm. (Accessed October 30, 2006.)

Encore Metals, 2006, AISI 3312, 4330, and 8620—Product manual: Encore Metals, Inc. Web site at http://www.encoremetals.com/docs/EncoreProductManualMay2006.pdf. (Accessed October 30, 2006.)

Environment Australia, 1999, Emission estimation technique manual for nickel concentrating, smelting, and refining: National Pollutant Inventory, 65 p. (also available online at http://www.npi.gov.au/handbooks/approved_handbooks/pubs/ fnickel.pdf.) (Accessed October 18, 2006.)

Fenton, M.D., 2005, Iron and steel scrap-2004: U.S. Geological Survey Minerals Yearbook 2004, v. I, p. 39.1-50.5. (Also available online at http://minerals.er.usgs.gov/minerals/pubs/ commodity/iron_\&_steel_scrap/fescrmyb04.pdf.)

Goles, G.G., 1967, Trace elements in ultramafic rocks, in Wyllie, P.J., ed., Ultramafic and related rocks: New York, John Wiley and Sons, Inc., p. 352-362.

Greetham, Geoff, 2003, Copper applications in industrial and marine applications: Copper Development Association Web site at http://www.copper.org/innovations/2003/11/ Cu_hull_sheathing_gg.htm. (Accessed September 27, 2006.)

INI International, 2006a, High-strength iron: Key to Metals Task Force and INI International Web site at http://www.key-to-steel.com/ViewArticle.asp?ID=21. (Accessed October 23, 2006.)

INI International, 2006b, Nickel and nickel alloys: Key to Metals Task Force and INI International Web site at http://www.key-to-nonferrous.com/default.aspx? $\mathrm{ID}=$ CheckArticle\&NM=9. (Accessed December 8, 2006.)

Internal Revenue Service, 1999, Market segment specialization program-Scrap metal industry: Internal Revenue Service Web site at http://www.irs.gov/pub/irs-mssp/scrap.pdf. (Accessed November 15, 2005.)

International Nickel Study Group, 2005, World nickel statisticsMonthly bulletin, v. 15, no. 6, June: The Hague, Netherlands, International Study Group, 1 CD-ROM.
International Stainless Steel Forum, 2006a, Stainless and heat resisting steel, crude steel production (ingot/slab equivalent): Web site at http://www.worldstainless.org/Statistics/ Crude/2002.htm. (Accessed June 2, 2006.)

International Stainless Steel Forum, 2006b, Foreign trade flow stainless steel scrap in 2002: Web site at http://www.worldstainless.org/Statistics/ Foreign+trade+scrap/2002.htm. (Accessed, June 21, 2006.)

International Stainless Steel Forum, 2006c, Foreign trade flow stainless steel scrap in 2003: Web site at http://www.worldstainless.org/Statistics/ Foreign+trade+scrap/2003.htm. (Accessed, June 21, 2006.)

International Stainless Steel Forum, 2006d, Foreign trade flow stainless steel scrap in 2004: Web site at http://www.worldstainless.org/Statistics/ Foreign+trade+scrap/2004.htm. (Accessed, June 21, 2006.)

Kelly, T.D., and Matos, G.R., 2006, Historical statistics for mineral and material commodities in the United States, nickel, end-use statistics: U.S. Geological Survey Data Series 140, available only online at http://minerals.usgs.gov/ds/2005/140/. (Accessed May 12, 2006, and periodically thereafter.)

Kuck, P.H., 2005, Nickel-2004: U.S. Geological Survey Minerals Yearbook 2004, v. I: Reston, Va., U.S. Geological Survey, p. 52.1-52.27. (Also available online at http://minerals.er.usgs.gov/minerals/pubs/commodity/nickel/ nickemyb04.pdf.)

London Metal Exchange, 2007, Nickel prices: Reported daily at Web site http://www.lme.co.uk/dataprices_daily_metal.asp.

Madani, Ali, 2003, The worldwide rechargeable battery market: Presentation by Avicenne Développment, Paris, France, for 2003 Taipei Power Forum \& Exhibition, Taipei, Taiwan, December 1-3, 2003. Plusdetudes Web site at http://www.plusdetudes.com/d02973044/COMPUTINGELECTRONICS-MEDIA-market-in-Taiwan-and-USA.html. (Accessed December 5, 2006.)

Mest, G.T., 2006, Nickel plating and troubleshooting: PF Online Web site at http://www.pfonline.com/articles/pfdmest01.html. (Accessed May 31, 2006.)

Nasir, M.I., 2001, Processing of spent nickel catalyst for fat recovery: Ciência Tecnologia Alimentos Campinas, v. 21, no. 1, January-April, p. 10-13. (Also available online at http://www. scielo.br/pdf/cta/v21n1/5356.pdf.)

Nickel Institute, 2003a, Commercial sector: Nickel Institute Web site at http://www.nickelinstitute.org/index.cfm/ci_id/135.htm. (Accessed May 12, 2006.)

Nickel Institute, 2003b, Industrial sector: Nickel Institute Web site at http://www.nickelinstitute.org/index.cfm/ci_id/136.htm. (Accessed May 12, 2006.)

Nickel Institute, 2003c, Transportation sector: Nickel Institute Web site at http://www.nickelinstitute.org/index.cfm/ci_id/137.htm. (Accessed May 12, 2006.)

Nickel Institute, 2003d, Building and construction sector: Nickel Institute Web site at http://www.nickelinstitute.org/index.cfm/ ci_id/138.htm. (Accessed May 12, 2006.)

Nickel Institute, 2003e, End-of-life recycling: Nickel Institute Web site at http://www.nickelinstitute.org/index.cfm/ci_id/126.htm. (Accessed May 12, 2006.)

OM Group, 2006, Nickel inorganics: OM Group Web site at http://www.omgi.com/product-ino-prod.html. (Accessed May 15, 2006.) 
PFOnline, 2006, Extending finishing bath life-How Astroplate extended bath life using filtration and other techniques: PFOnline Web site at http://www.pfonline.com/articles/099904. html. (Accessed August 28, 2006.)

Pointon, Chris, 2001, The future of nickel markets-Why nickel will outperform: Slide Presentation at $4^{\text {th }}$ Annual World Nickel Conference, Melbourne, Australia, November 8-9, 2001, 25 p. BHP Billiton Web site at http://www.bhpbilliton.com/ bbContentRepository/Presentations/CPslides.pdf. (accessed May 18, 2006.)

Precision Steel Warehouse, Inc., 2006, Stainless steel: Website at http://www.precisionsteel.com/products/default.asp?n_cat_ id=4. (Accessed June 19, 2006.)

Queneau, P.B., 2005, Recycling at U.S. plants operated solely to process metal-rich wastes: Presentation for Recycling Metals from Industrial Waste, A short course and workshop sponsored by the Colorado School of Mines, Office of Continuing Education, Golden, Colorado, June 2005. (Updated course information Web site at http://www.mines.edu/Outreach/ Cont_Ed/heavy.shtml.) (Accessed October 26, 2007.)

Rice Lake Weighing Systems, 2006, The appropriate application of stainless steel in the weighing and measurement industry: Rice Lake Weighing Systems Web site at http://www.ricelake. com/docs/ProdInfo/white-papers/wp_stainless_steel.pdf. (Accessed October 26, 2006.)

R.L. Polk and Company, 2005 (April 25), Hybrid vehicle registrations increase 81 percent in 2004: R.L. Polk and Company Web site at http://usa.polk.com/news/latestnews/ news_042505.htm. (Acccessed December 6, 2006.)

Rydh, C.J., and Svärd, Bo, 2003, Impact on global metal flows arising from the use of portable rechargeable batteries: The Science of Total Environment, v. 302, p. 167-184.

Sackett, P.S., 2005, Spent refining catalyst recycling-Past experiences and a view of the future: Presentation for Recycling Metals from Industrial Waste, A short course and workshop sponsored by the Colorado School of Mines, Office of Continuing Education, Golden, Colorado, June 2005. (Updated course information Web site at http://www.mines.edu/Outreach/Cont_Ed/heavy.shtml.) (Accessed October 26, 2007.)

Secretariat for Aluminum and Environment, 2006, Electroless nickel plating (Topic 14096): Secretariat for aluminum and environment-Aluminum for future generations, an association of the aluminum industry of Denmark. Secretariat for Aluminum and Environment Web site at www.alu.dk/videnbaser/modul/A00364.htm. (Accessed October 24, 2006.)

Smith, K.S., and Huyck, H.L.O., 1999, An overview of the abundance, relative mobility, bioavailability, and human toxicity of metals, in Plumlee, G.S., and Logsdon, J.J., eds., The environmental geochemistry of mineral deposits, Part A. Processes, techniques, and health issues: Society of Economic Geologists, Reviews in Economic Geology, v. 6A, p. 29-70.

Smiths Metal Centres, 2006, Nickel silver: Smiths Metal Centres Ltd. Web site at http://www.smithmetal.com/products/ nickelsilver.htm. (Accessed December 8, 2006.)

Steel Recycling Institute, 2005, The inherent recycling content of today's steel: Institute of Scrap Recycling Industries Website at http://www.recyclesteel.org/PDFs/Inherent04.pdf. (Accessed December 20, 2006.)

Terörde, Fritz, 2006, Stainless steel recycling_Data and scenarios and availability of scrap: Presenta- tion prepared by ELG, Haniel Group, Duisburg, Germany, March 2006. International Stainless Steel forum Website at http://www.worldstainless.org/NR/ rdonlyres/8FD08987-E98F-4BB8-9B33-99EEF0E8F938/2425/ StainlessSteelRecyclingAvailabilityofscrap.pdf. (Accessed December 4, 2006.)

Treadgold, Tim, 1998, WMC and the great nickel race: Minerals Gazette, v. 2, no. 15, p. 34-37.

Turekian, K.K., and Wedepohl, K.H., 1961, Distribution of the elements in some major units of the Earth's crust: Geological Society of America Bulletin, v. 72, p. 175-192.

U.S. Environmental Protection Agency, 2003, 2001 toxics release inventory executive summary: U.S. Environmental Protection Agency, Office of Environmental Information, Washington, D.C., p. 26. (Also available online at Web site http:/www.epa.gov/tri/tridata/tri01/press/executivesummarystandalone.pdf.) (Accessed April 12, 2007.)

U.S. Geological Survey, 1999, Nickel, in Metal prices in the United States through 1998: U.S. Geological Survey, Reston, Va., p. 91-97. (Also available online at http://minerals.er.usgs.gov/ minerals/pubs/metal_prices/). (Accessed March 17, 2008).

United States International Trade Commission, 2006a, Alloy steel exports 2004: Interactive Tariff and Trade DataWeb at http://dataweb.usitc.gov/scripts/user_set.asp, at which step, input parameters for report for alloy steel exports.

United States International Trade Commission, 2006b, Alloy steel imports, 2004: Interactive Tariff and Trade DataWeb at http://dataweb.usitc.gov/scripts/user_set.asp, at which step, select input parameters for report for alloy steel imports.

United States International Trade Commission, 2006c, Copper-nickel alloys exports 2004: Interactive Tariff and Trade DataWeb at http://dataweb.usitc.gov/scripts/user_set.asp, at which step, select input parameters for report for copper-nickel alloys exports.

United States International Trade Commission, 2006d, Coppernickel alloys imports 2004: Interactive Tariff and Trade DataWeb at http://dataweb.usitc.gov/scripts/user_set.asp, at which step, select input parameters for report for coppernickel alloys imports.

United States International Trade Commission, 2006e, Nickel exports 2004: Interactive Tariff and Trade DataWeb at http://dataweb.usitc.gov/scripts/user_set.asp, at which step, select input parameters for report for nickel exports.

United States International Trade Commission, 2006f, Nickel imports 2004: Interactive Tariff and Trade DataWeb at http://dataweb.usitc.gov/scripts/user_set.asp, at which step, select input parameters for report for nickel imports.

United States International Trade Commission, 2006g, Nickel alloy exports 2004: Interactive Tariff and Trade DataWeb at http://dataweb.usitc.gov/scripts/user_set.asp, at which step, select input parameters for report for nickel alloy exports.

United States International Trade Commission, 2006h, Nickel alloy imports 2004: Interactive Tariff and Trade DataWeb at http://dataweb.usitc.gov/scripts/user_set.asp, at which step, select input parameters for report for nickel alloy imports.

United States International Trade Commission, 2006i, Nickel chemical exports 2004: Interactive Tariff and Trade DataWeb at http://dataweb.usitc.gov/scripts/user_set.asp, at which step, select input parameters for report for nickel chemical exports.

United States International Trade Commission, 2006j, Nickel chemical imports 2004: Interactive Tariff and Trade DataWeb 
at http://dataweb.usitc.gov/scripts/user_set.asp, at which step, select input parameters for report for nickel chemical imports.

United States International Trade Commission, 2006k, Stainless steel exports 2004: Interactive Tariff and Trade DataWeb at http://dataweb.usitc.gov/scripts/user_set.asp, at which step, select input parameters for report for stainless steel exports.

United States International Trade Commission, 20061, Stainless steel imports 2004: Interactive Tariff and Trade DataWeb at http://dataweb.usitc.gov/scripts/user_set.asp, at which step, select input parameters for report for stainless steel imports.

United States International Trade Commission, 2006m, Superalloy exports 2004: Interactive Tariff and Trade DataWeb at http://dataweb.usitc.gov/scripts/user_set.asp, at which step, select input parameters for report for superalloy exports.

United States International Trade Commission, 2006n, Superalloy imports 2004: Interactive Tariff and Trade DataWeb at http://dataweb.usitc.gov/scripts/user_set.asp, at which step, select input parameters for report for superalloy imports.

Vangheluwe, Marnix, Verdonck, Frederik, and Versonnen, Bram, 2005, Contribution of spent batteries to the metal flows of municipal solid waste: Report prepared in behalf of RECHARGE aisbl, Brussels, Belgium, October, 2005, 79 p. EURAS Web site at http://www.rechargebatteries.org/ RelDoc_Metals_flow_of_MSW_2005_FL.pdf. (Accessed September 14, 2006.)

Warren, Tim, 2006, Recycling rechargeable batteries-A public service program from the Rechargeable Battery Recycling Corporation: Rechargeable Battery Recycling Corporation Web site at http://kdheks.gov/waste/works/06GreatBend/presentations/TimWarrenRBRC.pdf. (Accessed June 6, 2006.) 


\section{APPENDIX-DEFINITIONS}

apparent consumption. Primary plus secondary production (old scrap) plus imports minus exports plus adjustments for U.S. Government and industry stock changes.

apparent supply. Apparent consumption plus consumption of new scrap.

catalyst. A substance that changes the rate of a chemical reaction without being consumed in the reaction.

dissipative use. A use in which the metal is dispersed or scattered, such as paints or fertilizers, making it exceptionally difficult and costly to recycle or recover the metal.

downgraded scrap. Scrap intended for use in making a metal product of lower value than the metal product from which the scrap was derived.

hibernating scrap. Scrap that has reached the end of its useful economic life, but has not been collected (remains in place) pending economic conditions that warrant the effort to collect it.

martensitic stainless steel. Martensitic stainless steels are low-nickel grades of steel that were developed in order to provide a group of stainless-steel alloys that would be corrosion resistant and hardenable by heat treating.

new scrap. Scrap produced during the manufacture of metals and articles for both intermediate and ultimate consumption, including all defective finished or semifinished articles that must be reworked. Examples of new scrap are borings, castings, clippings, drosses, skims, and turnings. New scrap includes scrap generated at facilities that consume old scrap. Included as new scrap is prompt industrial scrap—scrap obtained from a facility separate from the recycling refiner, smelter, or processor. Excluded from new scrap is home scrap that is generated as process scrap and used in the same plant.

new-to-old-scrap ratio. New scrap consumption compared with old scrap consumption in the United States, measured in weight and expressed as:

for example, 40:60.

$$
\frac{\text { new scrap }}{\text { new }+ \text { old scrap }}: \frac{\text { old scrap }}{\text { new }+ \text { old scrap }} ;
$$

obsolete (end-of-service life). A material becomes obsolete when it no longer provides the desired services, or when humans value other services more than those provided by the material in question.

old scrap. Scrap including (but not limited to) metal articles that have been discarded after serving a useful purpose. Typical examples of old scrap are electrical wiring, lead-acid batteries, silver from photographic materials, metals from shredded cars and appliances, used aluminum beverage cans, spent catalysts, and tool bits. This is also referred to as post-consumer scrap and may originate from industry or the general public. Expended and obsolete materials used dissipatively, such as paints and fertilizers, are not included.

old scrap accounted for. Equals old scrap generated less old scrap unaccounted.

old scrap exports. The amount of old scrap exported from the United States in a subject year.

old scrap generated. The metal content of products from the U.S. product reservoir that theoretically becomes obsolete and available for recycling in a subject year. This definition excludes dissipative uses.

old scrap imports. The amount of old scrap imported to the United States in a subject year.

old scrap recovered and used. Equals old scrap generated less old scrap unaccounted for less old scrap deposited in landfills.

old scrap recycling efficiency. The amount of old scrap recovered and reused relative to the amount available to be recovered and reused. Defined as [consumption of old scrap (COS) plus exports of old scrap (OSE)] divided by [old scrap generated (OSG) plus imports of old scrap (OSI) plus a decrease in old scrap stocks (OSS) or minus an increase in old scrap stocks], measured in weight and expressed as a percentage:

$$
\text { COS + OSE }
$$$$
\text { OSG + OSI + decrease in OSS or - increase in OSS }
$$

old scrap supply (actual). Old scrap recovered and used plus old scrap inventory decrease plus old scrap imports.

old scrap supply (theoretical). Old scrap generated plus old scrap imported plus old scrap stock decrease.

old scrap unaccounted for. An artifact of materials flow accounting that represents the difference between old scrap generated (theoretically) from the product reservoir and old scrap recovered and used. This number expands if old scrap generated is overestimated, or if recovered scrap is underreported for whatever reason, or both.

old scrap unrecovered. Old scrap supply minus old scrap consumed minus old scrap exported minus old scrap stock increase.

price. Prices quoted are taken from public reports such as those of the London Metal Exchange.

primary nickel. Nickel extracted from oxide or sulfide ores and formed into products such as nickel metal, nickel oxide, ferronickel, and nickel-containing chemicals, which serve to carry the primary nickel into downstream production steps that require blends of nickel and other materials.

product reservoir. The stock materials serving consumer needs. It is also known as in-service stock or stock in use. When materials within the product reservoir reach 
their end of life (meaning end of utility), they become eligible for utility upgrade, one method of which is recycling as old scrap.

prompt scrap. New scrap generated in downstream facilities that returns quickly to upstream facilities according to some agreed prearrangement.

recycling. Reclamation of a metal in a useable form from scrap or waste. This includes recovery as the refined metal or as alloys, compounds, or mixtures that are useful. Examples of recycling are recovery of nickel from ferrous alloys such as stainless steel, from spent battery alloys, from nickel-sulfate solutions, and even the recovery of nickel from low-grade wastes such as drosses, dusts, skimmings, and slags.

recycling rate. Fraction of the apparent metal supply that is scrap on an annual basis. It is defined as [consumption of old scrap (COS) plus consumption of new scrap (CNS)] divided by apparent supply (AS), measured in weight and expressed as a percentage:

$$
\frac{\mathrm{COS}+\mathrm{CNS}}{\mathrm{AS}} \times 100
$$

scrap consumption. Scrap added to the production flow of a metal or metal product.

secondary nickel. Nickel recovered from scrap (clippings, cuttings, grindings, and turnings) and waste (flue dust, mill scale, grinding swarf, spent catalysts, filter cakes, pickling solutions, and spent rechargeable batteries).

superalloys. Alloys developed for high-temperature and high-stress service and where surface stability is frequently required. Superalloys are mixtures of Group VIIIB (Periodic Table of Elements) elements. Principal elements are chromium, cobalt, iron, and nickel. Less used elements are aluminum, molybdenum, niobium, tantalum, titanium, and tungsten.

swarf. Fine metallic particles and abrasive fragments removed by cutting or grinding tools.

ultramafic rocks. Rocks containing less than 45 percent silica. 